\title{
8
}

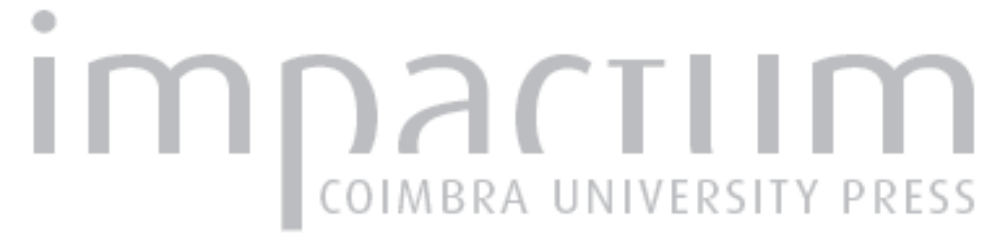

\section{Grécia e Roma na Revolução Francesa}

Autor(es): $\quad$ Ferreira, José Ribeiro

Publicado por: Imprensa da Universidade de Coimbra

URL persistente:

URI:http://hdl.handle.net/10316.2/43770

DOI:

DOI:https://doi.org/10.14195/2183-8925_10_11

Accessed : $\quad$ 26-Apr-2023 12:46:50

A navegação consulta e descarregamento dos títulos inseridos nas Bibliotecas Digitais UC Digitalis, UC Pombalina e UC Impactum, pressupõem a aceitação plena e sem reservas dos Termos e Condições de Uso destas Bibliotecas Digitais, disponíveis em https://digitalis.uc.pt/pt-pt/termos.

Conforme exposto nos referidos Termos e Condições de Uso, o descarregamento de títulos de acesso restrito requer uma licença válida de autorização devendo o utilizador aceder ao(s) documento(s) a partir de um endereço de IP da instituição detentora da supramencionada licença.

Ao utilizador é apenas permitido o descarregamento para uso pessoal, pelo que o emprego do(s) título(s) descarregado(s) para outro fim, designadamente comercial, carece de autorização do respetivo autor ou editor da obra.

Na medida em que todas as obras da UC Digitalis se encontram protegidas pelo Código do Direito de Autor e Direitos Conexos e demais legislação aplicável, toda a cópia, parcial ou total, deste documento, nos casos em que é legalmente admitida, deverá conter ou fazer-se acompanhar por este aviso. 
REVISTA DE HISTORIA DAS IDEIAS IO
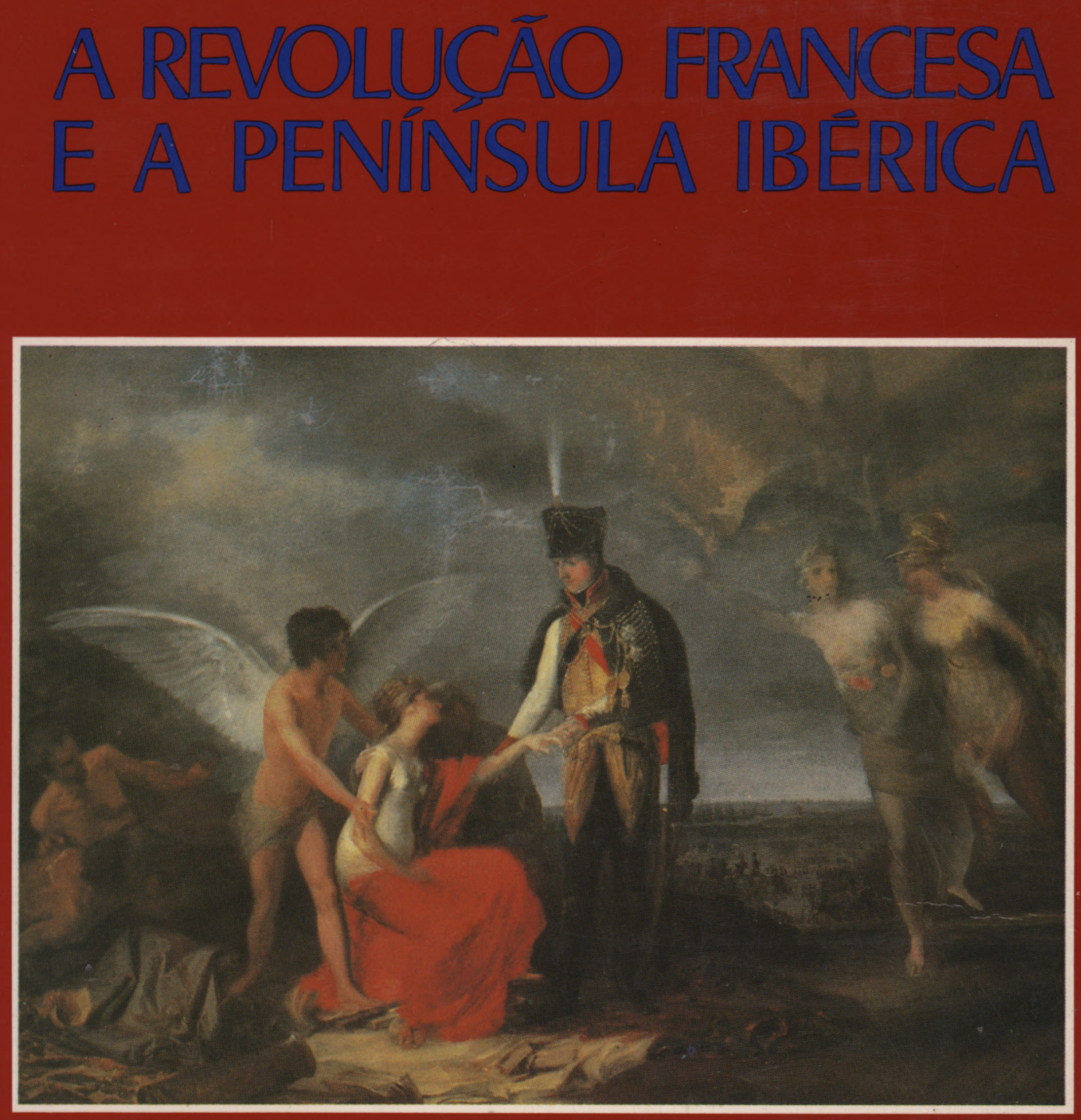

INSTITUTO DE HISTÖRIA E TEORIA DAS IDEIAS FACULDADE DE LETRAS 
JOSE RIBEIRO FERREIRA*

\section{GRÉCIA E ROMA NA REVOLUÇÃO FRANCESA}

Quem examinar determinados sucessos da Revolução Francesa, ler os seus textos programáticos ou folhear as páginas dos livros e panfletos dados à estampa pela camada dirigente, ficará surpreendido por um conjunto de factos e afirmações que, à primeira vista, se diriam paradoxais em pessoas e movimento que pretendem inovar e realizar uma revolução: notará referências constantes ao mundo greco-romano, bem elucidativas da identificação e do culto desses homens pelos valores $\epsilon$ figuras da Antiguidade Clássica. Não vou tratar aqui da influência nos campos literário e artístico, bastante bem conhecidos e frequentes vezes abordados $\left(^{(}\right)$. Referir-me-ei sobretudo à presença da Grécia e de Roma na Revolução Francesa, no domínio político, à influência dessas duas sociedades na actuação e oratória de muitos revolucionários, nas reformas e leis por eles propostas ou apoiadas.

1. Robespierre pensa que ele e os seus companheiros, quando abdicam do poder, depois de aprovarem a Constituição de 1791, estavam a imitar Licurgo. Marat, por ter impedido o destacamento real de atravessar a ponte sobre o Sena, é comparado a Horácio Cocles que sozinho bloqueou o avanço de Porsena na única ponte que ligava Roma à margem direita do Tibre (cf. Tito Lívio 2.10.12). Brissot, pela sua indepen-

* Faculdade de Letras da Universidade de Coimbra.

(1) Sobre a influência da cultura grega e romana em França na época das «luzes» e no período revolucionário vide L. Bertrand, La fin du clacissisme et le retour à l'antique dans la seconde moitié du XVIIIe siècle et les premières années du XIXe, en France, Genève, 1968, pp. 43-319. 
dência, considera-se Catão e muitos outros fazem o mesmo ou apontam-no como modelo a imitar ${ }^{(2)}$. Saint-Just, consciente dos seus méritos, cheio de ambição e desejoso de uma carreira condizente, imita Tarquínio e Cévola e anseia ser outro Licurgo ou Bruto $\left(^{3}\right)$. O revolucionário francês costumava consultar amiudadas vezes, na Convenção, a história da Antiguidade Clássica e invocava com admiração os heróis de Plutarco $\left.{ }^{4}\right)$. No discurso em que acusa Danton, em 31 de Março de 1794, Saint-Just proclamava que «le monde est vide depuis les Romains; et leur mémoire le remplit et prophétise encore la liberté» $\left({ }^{5}\right)$. As estátuas de Licurgo e Sólon, de Platão e Demóstenes, de Camilo, Publícola, Cincinato e Bruto encontravam-se em posição de destaque na sala de reuniões da Convenção $\left(^{6}\right)$. Por hábito que se torna mania, dão-se nomes de figuras da Antiguidade a ruas, a povoações e comunas ou às crianças recém-nascidas. Alguns líderes da Revolução substituem os seus nomes cristãos por outros de heróis da Antiguidade $\left({ }^{7}\right)$. Os revolucionários de Saint Maximin do Var, em

(2) Vide H.T. Parker, The Cult of Antiquity and the French Revolutionaries, Chicago, 1937, p. 89 (a partir de agora: Parker).

Sobre Horácio Cocles vide M.H. da Rocha Pereira, Estudos de História da Cultura Clássica. II - Cultura Romana, Lisboa, 1984, pp. 27-28; Walter de Medeiros, Plauto: O Gorgulho, introdução, versão do latim e notas, Coimbra, 1978, p. 175 nota 152; R.M. Ogilvie, A Commentary on Livy 1-5, Oxford, 1965, repr. 1978, pp. 258-261.

Catão de Ưtica é uma presença bastante assídua nos textos dos Revolucionários: e.g. Robespierre, La revolución jacobina (trad. esp.), Barcelona, 1973, pp. 44, 158; Saint-Just, Oeuvres Choisies, Paris, "Coll. idées", 1968, pp. 212, 264, 279.

(3) Carta a C. Desmoulins (Maio de 1790) in Oeuvres Complètes avec une introduction et des notes par Charles Vellay, Paris, 1908, vol. I, p. 221 (=Oeuvres choisies, Paris, "Coll. idées», 1968, p. 370); carta a Daubigny (20 de Julho de 1792) in Oeuvres Completes cit., I, p. 349 (=Oeuvres choisies cit., p. 372).

(4) A informação é dada por Barère. Cf. Aulard, "Une interview de Bertrand Barère in 1840», La Révolution française, 61 (1911), 55 (apud Parker, p. 45).

(5) Oeuvres Complètes (ed. Ch. Vellay), Paris, 1908, II, p. 331 (=Oeuvres Choisies cit., p. 249).

$\left.{ }^{\theta}\right)$ Cf. Parker, p. 144 e 146-147; Vidal-Naquet, "Tradition de la démocratie grecquen, prefácio a M.I. Finley, Démocratie antique et démocratie moderne (trad. franc.), Paris, 1976, pp. 26-27 (citado de futuro: Vidal-Naquet).

(7) Sobre o nome de Bruto, dado a várias povoações e recém-nascidos, e o caso de Babeuf que adopta, como prenomes, primeiro Camilo e depois Gaio Graco em substituição dos de baptismos, vide infra notas 52, 53 e 54. Para outros revolucionários que adoptaram nomes clássicos ou o deram aos filhos vide F. Diaz-Plaja, Griegos y Romanos en la revolución francesa, Madrid, 1960, p. 130 (a partir de agora: Diaz- 
1793, apresentaram à Convenção Nacional - talvez por intermédio de Lucien Bonaparte, que nessa altura presidia à referida comuna - uma petição em que solicitavam que a sua cidade tomasse o nome de Maratona, já que «ce nom sacré nous rapelle la plaine athénienne qui devint le tombeau de cent mille satellites: mais il nous rapelle avec encore plus de douceur la mémoire de l'ami du peuple», ou seja Marat ( $\left.{ }^{8}\right)$.

Se os exemplos até agora citados são significativos, não o é menos um outro protagonizado por Hérault de Séchelles, o principal redactor da Constituição de 1793. Em 7 de Junho desse mesmo ano escrevia ele ao Conservador da Biblioteca Nacional de Paris:

«Chargé avec quatre de mes collègues de présenter pour lundi un plan de constitution, je vous prie, en leur nom et au mien, de nous procurer sur-le-champ les lois de Minos, qui doivent se trouver dans un recueil des lois grecques. Nous en avons un besoin urgent» $\left({ }^{9}\right)$.

$\mathbf{E}$ os exemplos poderiam multiplicar-se quase indefinidamente $\left({ }^{10}\right)$. São referências elucidativas da identificação de cada dirigente da Revolução Francesa com o mundo greco-romano e do culto desses homens pelos valores e figuras dessas sociedades.

A maior parte deles acreditava que o passado da Antiguidade Clássica tinha algo a ensinar à França ${ }^{(11)}$. Essa crença

-Plaja); E. Rawson, The Spartan Tradition in European Thought, Oxford, 1969, pp. 285 e 287 (de futuro: Rawson).

(8) Cf. Guillaume, Procès-verbaux du Comité d'Instruction publique de la Convention Nationale, Paris, 1957, III, pp. 620-621 e VII, fasc. 2, p. 40 (a partir de agora: Guillaume, Procès-Verbaux); Parker, pp. 141-142.

(9) Vide E. Dard, Hérault de Séchelles (1759-1794) d'après des Documents inédits, Paris, 21907, p. 223. Esta carta mereceu a ironia sarcástica de Taine, Origines de la France contemporaine. La Révolution, tome III - Le gouvernement revolutionnaire, Paris, 131892, p. 8: visava-se uma obra de fachada e de propaganda, não algo que tivesse em conta a realidade.

(10) Sobre o assunto e para outros exemplos vide Parker, passim; F. Diaz-Plaja, passim; Rawson, pp. 268-300; J. Starobinski, 1789. Les emblèmes de la Raison, Paris, 1973; P. Vidal-Naquet.

(11) São excepção, entre outros, Condorcet, Kersaint, Montlosịer, Cazelès. Condorcet considerava os modernos superiores, pelo que os antigos não tinham nada a ensinar-lhes. Apenas admite a superioridade destes em política antes de 1776, altura da Revolução da América. Condorcet, um dos poucos que tinham consciência da luta entre Antigos e Modernos, considerava que, em poesia e teatro, saber, cultura e direito, os Modernos eram superiores aos Antigos. Em consequência da Revolução e independência dos Estados Unidos da América, a partir 
adquirem-na e cimentam-na nos collèges que a maioria frequentou, em Paris ou na província, no contacto com os livros de autores antigos - na sua quase totalidade latinos - estudados e comentados nesses estabelecimentos de ensino. Terminada a época escolar, mantêm a convivência com os autores clássicos, sobretudo com Tito Lívio, Cícero, Virgílio, Salústio, Séneca, Plutarco, entre outros; alargam mesmo o âmbito da sua leitura ${ }^{\left({ }^{12}\right)}$.

As obras e passos preferidos, ou pelo menos mais lidos, de modo geral referiam-se a um passado grandioso e idealizado da Grécia e de Roma, exaltavam as virtudes e heróis que a uma e a outra tinham dado fama e tornado poderosas - exaltação que era muitas vezes acentuada pelos professores e comentadores desses tempos $\left.{ }^{(13}\right)$.

$\mathrm{Da}$ Grécia a leitura de Plutarco exalta uma idade de ouro que termina, em Atenas, com a morte de Péricles e, em Esparta, com a de Lisandro $\left(^{14}\right)$. Essa Hélade descrita nas Vidas Paralelas povoa-se de heróis, cujas virtudes convidam à imitação: Atenas surge aí com mais liberdade para os cidadãos, Esparta com mais igualdade do que a existente na França do século XVIII;

de 1780, Condorcet menciona as instituições dos Antigos apenas com desprezo e desdém (cf. "Discours dans la Académie française (1782-1784)", Oeuvres, Paris, 1847-1849, repr. Stuttgart, 1968, I, pp. $403-404$ e 446-447; "Éloge de Blondel», Oeuvres, II, p. 41; "Éloge de Franklin», Oeuvres III, pp. 372-374, 382-383, 402-403; "Éloge de l'Hôpital», Oeuvres III, pp. 534-535, 551; «Réflexions sur l'esclavage des nègres», Oeuvres VII, pp. 97-99; "Sur l'instruction publique», Oeuvres VII, pp. 202-203, 268-269, 278-279, 374-375; "Réflexion sur le commerce des blés», Oeuvres $\mathrm{Xl}, \mathrm{pp} .157-158$ e 185 .

(12) A importância dada ao estudo dos autores gregos nos currículos dos Collèges era pouca, ou nula mesmo (vide infra, nota 50). Os jovens, contudo, manifestavam uma preferência acentuada por Plutarco, que conheciam em tradução, como aconteceu com Mme Rolland que confessa tê-lo lido aos oito ou nove anos na versão de Dacier, Les vies des hommes illustres de Plutarque traduites par...., Paris, 1762 (cf. Mémoires I, Paris, 1827, p. 25). No quadro apresentado por Parker, pp. 18-19, vemos que, depois de Cícero citado oitenta e três vezes, Plutarco é o mais contemplado com 36 citações, de par com Horácio. Sobre as obras dos autores antigos estudados vide Parker, pp. 14 e ss. A lista fornecida por Diaz-Plaja, pp. 141-145, relativa às obras mais traduzidas em França, no séc. XVIII e primeiros anos do XIX, e número de ediçôes, dá ideia das que mais influência exerceram.

(13) Segundo parece os estudos clássicos nos Collèges realçavam de modo especial a Conjura de Catilina de Salústio, os livros I-III e XXI de Tito Lívio, os seis primeiros cantos da Eneida de Virgílio. Para os textos dados e que realçavam o passado da Grécia e de Roma Vide Parker, pp. 20-28; para os comentadores, pp. 28-33.

(14) Plutarco, Péricles 39; Lisandro 30. 
a ruína das duas referidas cidades aparece atribuída ao aumento da riqueza e ao declínio da virtude $\left({ }^{15}\right)$.

De Roma, esses textos transmitem uma visão da época republicana do passado e exaltam as virtudes que a fizeram grande e poderosa: frugalidade, simplicidade, honestidade, diligência, temperança, autodomínio, coragem, integridade, justiça, amor à pátria e amor à liberdade ${ }^{(16)}$.

Deste modo a geração revolucionária, na leitura dos autores antigos, era convidada a admirar as virtudes e liberdades republicanas da Grécia e de Roma e incitada a seguir o exemplo dos seus heróis e governantes $\left(^{17}\right)$.

Brissot de Warville, um líder da Gironda, conta que, no último ano de estudante o seu desejo de fama e os seus sonhos eram satisfeitos na leitura de livros, sobretudo Plutarco, e ansiava assemelhar-se a Fócion $\left({ }^{18}\right)$. Mme Rolland confessa que o contacto com Plutarco a tornou republicana e que, em criança e na juventude, as Vidas Paralelas, que ela chegava a levar para a igreja em vez do livro de orações, a transportavam para o passado da Grécia e de Roma, a faziam identificar-se com os heróis aí biografados e compartilhar as suas paixões; lamentava mesmo não ter nascido espartana ou romana $\left({ }^{19}\right)$. Mercier revela que, durante os seus estudos, ao ler os clássicos, actuava em consonância com as figuras históricas: fazia a guerra a Aníbal, destruía Cartago, seguia a marcha triunfante das legiões sobre a Gália, conquistava sem horror o país em que nasceu. Em sua opinião, o estudo da língua latina incute o gosto pelas repúblicas e cria o desejo de ser capaz de ressuscitar a república particular cuja história se está a ler $\left({ }^{20}\right)$. Para Camille Desmoulins, a visão da Antiguidade republicana, haurida no seu tempo de estudante com a leitura dos autores antigos, trans-

(15) Plutarco, Licurgo 24 e 29-30. E um facto que a visão de Plutarco é falseadora e não dá uma perspectiva correcta de Esparta e de Atenas. No entanto Plutarco, como Tito Lívio, considerava que a missão da história era ensinar - ensinar a sabedoria e a virtude por meio de exemplos descritos e oferecidos à imitação. Sobre o assunto vide Parker, pp. 27-29.

(16) Vide Saint-Just, Oeuvres choisies cit., p. 118; Robespierre, La revolución jacobina cit., p. 138 . Vide $\mathrm{C1}$. Nicolet, L'idée républicaine en France. Essai d'histoire critique, Paris, 1982, pp. 18-19.

(17) Exemplos vários em Parker, pp. 23-26.

(18) Mémoires (1754-1793) publ. par Cl. Perroud, Paris [1911], vol. I, p. 42.

(19) Mémoires, Paris, 1827, vol. I, p. 25 e II, p. 99. Outros exemplos em Parker, pp. 39-42.

(20) Tableau de Paris, Amsterdam, 1785, pp. 151-152. Observe-se, no entanto, que o seu entusiasmo pela república de Roma se desvanece e que Mercier se tornará um súbdito leal da monarquia. 
mitiu-lhe o primeiro amor à liberdade e o primeiro ódio à monarquia; confessa que nessa altura se sentia desesperado por não ter nascido grego ou romano $\left({ }^{21}\right)$.

Este entusiasmo origina a comparação do presente com esse passado distante, de modo geral idealizado - comparação essa que conduz a descontentamento e insatisfação perante as instituições monárquicas francesas e desejo de mudança.

Apesar de certa evolução no conceito que alguns formavam dela, os revolucionários concebiam a Antiguidade Clássica, sobretudo Esparta e Roma, como um paraíso, em que o mérito era reconhecido e onde vigorava a liberdade, a igualdade e a virtude; a austeridade e a frugalidade; a coragem e o amor da pátria ${ }^{22}$ ). Trata-se de uma concepção cimentada nos «filósofos» da «época das luzes», sobretudo Montesquieu e Rousseau, que ensinavam serem tais virtudes necessárias à república. Em outro aspecto há influência desses mesmos «filósofos»: a noção de que a república só seria possível em Estados pequenos como eram os da Antiguidade Clássica. Sempre que o seu território crescia para além de certos limites, verificava-se a queda da república, como acontecera em Roma ${ }^{(23)}$. $\mathrm{Na}$ sua peugada, alguns dos futuros revolucionários, nos anos subsequentes à saída dos estabelecimentos de ensino e antes dos eventos de 1789 , manifestaram um certo desânimo e lamentaram a impossibili-

(21) La France libre, in Oeuvres I, pp. 60-63 e 69.

(22) Encontramos afirmações nesse sentido, entre outros, em Robespierre, Marat, Brissot, Mme Rolland, Barère, Vergniaud. Vide Parker, pp. 47-61 e 68, nota 15.

(23) Montesquieu, Considérations sur les causes de la grandeur des Romains et de leur décadence, in Oeuvres complètes II, Bibliothèque de la Pléiade, Paris, 1951, pp. 67 e ss., em especial 116-122; De l'esprit des lois, in Oeuvres Complètes II, pp. 252-253, 270-272, 302, 334-335, 346-347. Montesquieu e Rousseau haviam observado que em Esparta e Roma a república, a liberdade e a igualdade políticas tinham declinado quando a virtude, política e privada, decaíra, em consequência do aparecimento da riqueza, do luxo e da desigualdade de fortuna. Montesquieu e Rousseau constatam, além disso, que as repúblicas só se mantêm em estados de pequena área e de reduzida população, como o mostra Roma, cuja república caíu quando se tornou demasiado grande. Daí a conclusão de que a virtude é indispensável à república e que esta só é possível conservar-se em estados de reduzida dimensão.

Sobre a importância da virtude para a república vide ainda $\mathbf{M}$. Servan, "Discours sur les moeurs", in Brissot, Bibliothèque philosophique, Paris, 1782, VII, pp. 19-20.

Sobre a influência greco-latina no "Século das Luzes", em especial em Montesquieu e Rousseau, vide Parker, pp. 62-63; Diaz-Plaja, pp. 8-15; Rawson, pp. 227 e ss. 
dade de tornar a França uma república, dotada de instituições semelhantes às da Grécia e de Roma $\left({ }^{24}\right)$.

O fermento estava lançado. A leitura dos autores antigos e o convívio com a história e instituições da Grécia e de Roma originaram, pelo menos indirectamente, uma mudança psicológica. Concebidas como perfeitas em comparação com a França em que viviam, a imitação do exemplo das comunidades clássicas significava uma mudança radical. A comparação tornava os homens insatisfeitos com a sociedade em que viviam, transmitia-lhes a ideia de que algo de novo seria possível, dava-lhes a certeza de que essa nova ordem era praticável ${ }^{(25)}$. Assim, na mente desses homens, a Revolução - como dizia Chateaubriand - «estava concluída antes de se ter realizado" $\left({ }^{26}\right)$.

A declaração da independência dos Estados Unidos da América veio provar-lhes da possibilidade de uma república num Estado de área extensa ${ }^{27}$ ); os acontecimentos de 1789, além de lhes revigorarem de novo a esperança de verem a França com instituições e costumes semelhantes aos da Antiguidade Clássica, ofereceram-lhes ocasião de porem em prática as reformas que há muito lhes viviam na mente.

Evidentemente que, no intenso confronto ideológico e na luta política que então se verifica - e sempre acontece em momentos semelhantes -, não têm todos a mesma visão da Antiguidade Clássica e nem todos acham benéfica a imitação das suas instituições, dos seus costumes - enfim da sua virtude como os revolucionários tanto gostavam de dizer $\left({ }^{28}\right)$. Para uns, a Revolução Francesa deu origem a uma constituição ou oferece a promessa de criar um povo: uma e outro lhes pareciam superiores aos das repúblicas da Grécia e de Roma, pelo que - argu-

(24) Brissot, por exemplo, lamentando o facto, considera as leis de Licurgo inaplicáveis à França e que nenhuma lei ou instituição pode ressuscitar a virtude romana. Cf. Theorie des loix criminelles, Neuchatel, 1781, I, pp. 44-47, 106 nota 46, 210-213, 231-232, 235, 264; «Recherches philosophiques sur le droit de propriété et le vol.n, in Bibliothèque philosophique VI, pp. 291-293.

Para outros exemplos vide Parker, pp. 63-65.

(25) Vide Parker, pp. 68-70.

(26) Apud Parker, p. 68.

(27) Brissot considerava a constituição americana superior, facto que o leva a manifestar desdém pela inferior organização governamental da democrática Atenas e da aristocrática Roma. Vide Parker, p. 96.

Condorcet que, antes da Revolução Americana, ainda considerava as repúblicas antigas superiores no que respeita à organização política, desde essa data passa também a considerá-las inferiores.

(28) Sobre a virtude e sua importância vide Saint-Just, Oeuvres choisies cit., pp. 118, 219-220, 308-309, 325, 327, 332-337; Robespierre, La revolución jacobina cit., pp. 39, 112, 138, 141-143, 153. 
mentavam eles - os Franceses não precisavam mais de admirar aquelas sociedades $\left({ }^{29}\right)$. Mas se estes se opunham à imitação da Antiguidade Clássica, por considerarem superior o produto moderno, boa parte dos conservadores e monárquicos fazia-o por razões bem diferentes. Via na Antiguidade Clássica um exemplo que não devia ser seguido: de índole republicana e com instituições democráticas, a Grécia e Rcma tinham incutido em muitos o amor à liberdade e à república e o concomitante ódio à monarquia. Para eles, a liberdade desses Estados era condenável pelo facto de ser liberdade; imitar as suas instituições em nada seria benéfico para a França, já que - prediziam - a adopção de tais instituições e normas democráticas seria fonte de anarquia e tumulto $\left(^{30}\right)$. O carácter benéfico ou nocivo da imitação da Grécia e de Roma constituirá um dos vectores da fractura entre os monárquicos e os republicanos e esteve no centro da discussão entre uns e outros $\left({ }^{31}\right)$.

Para os republicanos, a monarquia, governo de um só, constitui uma tirania e um atentado à liberdade; ainda a admitem como aceitável no caso de ser legitimada pelo povo e de se submeter às leis. Encontramos estas noções expressas com bastante nitidez em Saint-Just, em Camille Desmoulins e em Robespierre, entre outros.

Desmoulins considera os reis bons para o teatro, como actores. No resto não são precisos $\left({ }^{32}\right)$. Traça um breve esboço dos reis de F'rança e sublinna não ser possível sair dessa galeria «sans proférer tous ce mot que les enfans savaient dire à sparte:

(29) Desmoulins, que foi um ardente admirador de Atenas e de Sólon e mais tarde a esse propósito, como se refere adiante, manterá um vivo debate com os dirigentes do Terror, exalta a moderação dos Franceses durante a Revolução, considerando que de modo algum foram tão cruéis como os Atenienses e os Romanos (Révolutions de France, n.o 28, p. 203). Mme Rolland, carta de 1790, Julho 18, in Lettres 1780-1793 II, pp. 107-108 manifesta um sentimento idêntico ao de Desmoulins. Para estes e outros exemplos vide Parker, pp. 96-102. Sobre Condorcet vide supra nota 11 .

(30) Os conservadores e monárquicos alegavam ainda-utilizando aliás os raciocínios dos «filósofos» - que a queda da república eilı Roma, quando esta cidade se torna territorialmente extensa, mostra que a república não é aplicável em França; por isso não deve ser introduzida.

Argumentam os republicanos, de que cito Lavicommterie, Condercet, Carra, que, antes de a república cair, Roma governou gloriosamente sobre um vasto território, mais vasto mesmo que a França. Vide Parker, pp. 104-109; Diaz-Plaja, pp. 18-22.

(31) Tanto os defensores do rei como os que o condenam recorrem com abundância aos exemplos da Grécia e de Roma. Vide Diaz-Plaja, pp. 51-56.

(32) Oeuvres IV, p. 112. 


\section{Grécia e Roma na Revolução Francesa}

je ne serai point esclave» $\left({ }^{33}\right)$. Desmoulins confessa que a monarquia lhe era odiosa $\left({ }^{34}\right)$. Comprova que em todos os povos, mesmo nos mais subjugados, há almas republicanas: homens em que o amor da liberdade triunfa, como aconteceu com Catão de Útica que preferiu imolar-se por amor dessa liberdade a viver como súbdito de um rei - César. Para Desmoulins, a nação deve governar-se a si mesma, a exemplo do que fazia a Grécia. Só assim os cidadãos gozariam de liberdade. Porquê - pergunta ele - colocar o destino de um povo ou as suas esperanças nas mãos de um só homem? $\left({ }^{35}\right)$.

Para Robespierre, no processo de Luís XVI está em jogo a república, a justiça, a liberdade e a virtude contra a monarquia, o despotismo, a tirania e o crime. Por isso, nem sequer se deve submeter o rei a julgamento: seria admitir a possibilidade da sua inocência. Se Cromwell julgou Carlos I e Isabel julgou Maria Stuart, fizeram-no como tiranos que imolam outros tiranos à sua ambição, e não a princípios de liberdade. Em nenhuma república foi alguma vez impugnada a necessidade de castigar um tirano, como fez Roma a Tarquínio. Os defensores do rei são partidários da tirania e querem restabelecer a monarquia. Quando um rei é anulado ou destituído pelo povo, perde a legitimidade. Respeitá-lo é desrespeitar o povo, defender Luís XVI é blasfemar contra a república e reanimar o espírito monárquico $\left.{ }^{(36}\right)$.

Saint-Just considera a monarquia opressão, governo de um tirano que está acima das leis; um regime em que vigora o vício e o crime, em que a falsidade e o dolo recebem honras, o sentimento e a amizade são coisas ridículas, que faz da desconfiança prudência. Aduz o exemplo de Bruto e aconselha por isso os franceses a destruírem a monarquia, já que não tem razão de ser, por desprovida de representação e moralidade; incita-os a tomarem a iniciativa de, pela morte do tirano, libertarem o mundo $\left.{ }^{(37}\right)$.

(33) Oeuvres I, pp. 31-54. Citação da p. 32.

(34) Oeuvres I, p. 63.

(35) Oeuvres I, pp. 54 ss. (em especial pp. 56-59 e 63-64).

(36) Vide "Discurso sobre o processo do Rei», pronunciado na Convenção em 3 de Dezembro de 1792, in La Revolución jacobina cit., pp. $74-84$ (em esp. 75, 76-77, 78, 80 e 83).

(57) Tais ideias aparecem expostas, em especial, no «Discurso sobre o julgamento de Luís XVI» e «Segundo discurso sobre o julgamento de Luís XVI», proferidos na Convenção em 13 de Novembro e 27 de Dezembro de 1792, respectivamente; no "Discurso sobre a Constituição da França», de 24 de Abril de 1793, e no "Relatório sobre os suspeitos encarcerados", de 26 de Fevereiro de 1794: Oeuvres choisies cit., pp. 74-83, 92-102, 113-123 e 189-204, respectivamente. Vide em especial pp. 77, 93-94, 98-99, 101, 102, 119-120, 193 e 194. 
Em muitas das páginas dos revolucionários franceses sente-se ressoar a dicotomia entre governo do tirano, ou de um só, e governo legitimado pelo povo, pelo dêmos, que foi motivo de tantos debates na Grécia - em especial em Atenas - e em Roma e surge em diversos autores antigos $\left({ }^{38}\right)$.

E exemplar e significativo um passo de Saint-Just, do Discurso sobre a Constituição da França que de imediato traz à memória as críticas de Otanes ao governo de um só no cap. 80 do livro III de Heródoto e as de Teseu nos versos 444 ss. das Suplicantes de Eurípides. Saint-Just, ao apontar os malefícios do regime monárquico, refere que a tirania deprava o homem, tornando-o aos seus próprios olhos incapaz do bem, e que ela «est intéressée à la mollesse du peuple. Elle est intéressée aux crimes. Elle est de moitié dans toutes les bassesses et les attentats; elle arma le fils contre le père par la loi civile.... C'est elle qui corrompt les coeurs et les déprave sous le joug. Elle endort l'âme humaine» ${ }^{39}$ ).

Como em Saint-Just, também nos passos de Heródoto e de Eurípides o tirano é acusado de acreditar que pode agir sem prestar contas; de ser insolente e cometer os mais variados crimes; de odiar e eliminar, sem julgamento, os melhores cidadãos, por inveja ou receio; de lhes desonrar as mulheres e as filhas e de se apoderar das riquezas. Daí que ninguém se esforce por enriquecer o tirano e que o desinteresse se estenda por todo o país $\left({ }^{40}\right)$.

A este propósitc e relacionado com a soberania do povo, convém recordar que alguns artigos da Declaração dos Direitos do Homem $e$ do Cidadão apresentam relações estreitas com a Antiguidade Clássica. Destaco os art. ${ }^{\circ} 18$ (=16 no texto de

(38) Recordo Heródoto 3.80; Ésquilo, Suplicanties, 366 ss.; Sófocles, Antígona, 640 ss. (em especial 727-739); Eurípides, Suplicantes, 399 ss.; Cícero, Rep. 1.3350 e $44.68 ; 2.27 .49$ e 29.51; 3.31.43; Leg. 1.15: Tácito, Hist. 1.1 e 1.16. Vide José Ribeiro Ferreira, Hélade e Helenos. I Génese e Evolução de um conceito, Coimbra, 1983, pp. 235-238 e «Asnectos políticos nas Suplicantes de Eurípides», Humanitas $37-38$ (1985-1986), pp. 93-103.

(39) Oeuvres choisies cit., p. 120. Na edição de Soboul, Discours et Rapports, - a que apenas tive acesso na tradução portuguesa Saint-Just, Discursos e Relatórios, 1975, p. 71 - o passo relativo aos malefícios da tirania é mais extenso.

(40) Sobre o texto de Heródoto e os problemas levantados pela veracidade do debate vide T.A. Sinclair, $A$ History of Greek Political Thought, London, 1967, pp. 36-42; M.H. da Rocha Pereira, "O mais antigo texto de teoria política", Nova Renascença 4, Verão de 1981, pp. $364-367$.

Sobre o de Eurípides vide J. Ribeiro Ferreira, «Aspectos políticos nas Suplicantes de Eurípides», Humanitas 37-38, pp. 96-97. 


\section{Grécia e Roma na Revolução Francesa}

1789) e o 19 (=21 no de 1789). O art. 16 - «a lei deve ser igual para todos» - não é mais do que uma paráfrase do termo isonomia, uma característica fundamental da democracia ateniense, a ponto de com ela se identificar $\left({ }^{41}\right)$. $\mathrm{O}$ art. ${ }^{\circ} 19$, ao estipular que todos os cidadãos são admissíveis a qualquer função pública, sem outra distinção que a das suas virtudes e talentos, apresenta um clausulado condizente com o que afirma Péricles na Oração fúnebre que lhe atribui Tucídides 2.37.1: em Atenas as honras e cargos públicos não eram concedidos com base na classe social, mas no mérito ${ }^{\left({ }^{42}\right)}$.

Republicanos convictos, a maioria da classe dirigente, sobretudo os líderes que mais influência tiveram no evoluir dos acontecimentos até ao 9 Thermidor, acreditava na superioridade das sociedades da Antiguidade Clássica e defendia que a França só beneficiava com a emulação dos seus heróis e a imitação das suas instituições e costumes.

O confronto entre imitadores e detractores da Antiguidade Clássica pode mesmo reflectir cambiantes ideológicas. O estudo dos debates na Assembleia Constituinte (1789-1791), permite segundo Parker (pp. 83-85), concluir que os elementos de direita e de extrema direita, embora acreditem que a Antiguidade Clássica pode ensinar alguma coisa à sociedade do seu tempo, condenam-na mais vezes, numa proporção de dois para um, do que por ela manifestam admiração e defendem a sua imitação; nos que ideologicamente se situam ao centro verifica-se uma proporção inversa; nos revolucionários da esquerda e da extrema esquerda as referências que manifestam admiração e propõem a imitação ultrapassam as que condenam essa imitação numa proporção de quatro para um e de três para um, respectivamente.

Durante a. Assembleia Constituinte e a Assembleia Legislativa, vários deputados e jornalistas - caso de Gorsas, Laustalof, Desmoulins, Lavicomterie, Billaud-Varenne, Dumouchet e às vezes Brissot - defendem a adopção de algumas reformas imitadas da Grécia e de Roma, não como um fim em si, mas como um meio de preservar a liberdade, a virtude e o amor

(41) Cito pelo texto de 1793, apresentado por Robespierre aos Jacobinos em 21 de Abril desse ano: in P. Kessel, Les gauchistes de 89, Paris, 1969, pp. 86-92. Para a importância da isonomia em Atenas vide infra nota 103.

(42) Cf. também a Declaração solene dos direitos do homem no Estado social, onde, no artigo 6, da afirmação de que a igualdade deriva da liberdade, extrai várias consequências entre as auais está a da admissibilidade dos cidadãos a quaisquer funções públicas, sem distinção de nascimento, fortuna ou estado, mas segundo a sua capacidade (apud Kessel, Les gauchistes de 89 cit., p. 99). 
do bem comum. Mas as referências à Antiguidade Clássica e as propostas de incentivo à sua imitação parecem ter esmorecido durante a Assembleia Legislativa (1791 a Setembro de 1792) e surgem outras opiniões coincidentes com a de Condorcet, para quem a França não necessitava de imitar a Antiguidade Clássica $\left({ }^{43}\right)$.

E durante a Convenção Nacional que o exemplo da Grécia e de Roma volta a assumir papel decisivo. Abolida a monarquia e proclamada a república, os membros desse órgão que mais influência tiveram no evoluir dos acontecimentos - Billaud-Varenne, Saint-Just, Robespierre - consideram que, para a conservar, seria necessário que os franceses, ainda degenerados e depravados, fossem regenerados através de uma reforma institucional cuidadosamente planeada, capaz de incutir neles a virtude $\left.{ }^{(44}\right)$. Pretendem para os seus compatriotas uma felicidade plena e mais virtuosa, que pressupõe cidadãos também mais virtuosos. Daí a necessidade de regeneração por meio de instituições virtuosas e do terror para conter os incorrigíveis $\left({ }^{45}\right)$.

Acreditavam que conseguiriam essa transformação fazendo reviver as virtudes das repúblicas da Antiguidade Clássica. Por isso procuram ressuscitar no seu país as instituições que

(43) São algumas dessas reformas solicitadas a criação dos tribunos e dos censores, a adopção do referendo, direito de voto não sujeito a qualquer qualificação económica, exército de cidadãos, eleição dos generais e embaixadores do povo, decisão da guerra e da paz pelos seus representantes. Vide Parker, pp. 94-95 e 110-118.

Apesar do esmorecimento verificado durante a Assembleia Legislativa, observe-se que, durante esse período, os "emigrados» são apodados de Catilinas; as hostes austríacas invasoras são assemelhadas à invasão da Grécia por Xerxes, enquanto os exércitos franceses são corajosos Romanos ou são Atenienses e Espartanos prontos a morrer pela liberdade nas Termópilas ou a vencer em Maratona; Lafavette, aue deixa o exército para vir a Paris falar na Assembleia dos Jacobinos, é comparado a César. Vide Parker, p. 118.

(44) 0 membro da convencão considerava-se senhor do seu destino. omnipotente como legislador e invencível pelo estrangeiro. Neste esvírito bem diferente da resignação anterior a 1789 a a imitação da Antiguidade Clássica que lhes parecera uma imnossibilidade surge-lhe agora como uma eminente e prática realidade. Durante o período do Terror o recurso aos exemplos da Grécia e de Roma são constantes, tanto por parte dos situacionistas como pelos seus opositores. Vide Diaz-Plaia, no. 22-31. Sobre a imnortância da virtude vide infra nota 61 .

(45) Saint-Just que, nos Fragments (in Oeuvres choisies cit.. p. 327). refere que «um governo republicano tem a virtude por princípion, e Robespierre, que vê na virtude política um princípio fundamental do governo democrático e popular, consideram essa virtude necessária às snciedades e afirmam aue realiznu nrodígios na Grécia e em Roma. Cf Saint-Irist. nb. cit., pp. 332-333; 358; Robespierre, La Revolución jaco. bina, pp. 39, 138. Vide supra nota 28 . 
vigoravam nos dias gloriosos da Grécia e de Roma, onde - aliás de acordo com o que aconselhavam Montesquieu, Rousseau e Mably e com o que haviam já proposto vários deputados e jornalistas no decorrer da Assembleia Constituinte e da Assembleia Legislativa - vão buscar o modelo ou sugestão de algumas medidas. Roma sugere-lhes a criação da censura, da ditadura e do tribunado $\left(^{46}\right)$. Da Grécia, os festivais desportivos e o tipo de educação, em especial o de Esparta, inspiram a ideia da instituição de festivais públicos nacionais e a adopção de muitas das normas e práticas educativas dos planos e projectos de educação que, do inverno de 1792 ao outcno de 1793, foram apresentados e discutidos na Convenção Nacional ou no seu Comité de Instrução Pública. Dentre esses vários projectos destaco o de J.-P. Rabaut, proposto em 21 de Dezembro de 1792; o do próprio Comité em cuja redacção Sieyès tem papel preponderante, lido por Lakanal em 26 de Junho de 1793; o de Michel Lepeletier aceite em 13 de Julho, embora concluído mais cedo; o de A. Deleyre apresentado em Julho; o de Marie-Joseph Chénier, em 5 de Novembro ${ }^{\left({ }^{47}\right)}$.

(46) J.-P. Rabaut, tendo por modelos Esparta e Roma, considerava que as leis das repúblicas da Antiguidade Clássica eram muitas vezes fruto de grande sabedoria. Aconselhava por isso a sua imitação (Chronique de Paris 6 (Jan. 6, 1793), p. 22). Em sintonia Mably e Montesquieu s:gerem ao legislador que aprenda, nas maneiras e moral austeras dos Espartanos, como a república se deve constituir e, nos métodos utilizados na Antiguidade Clássica, como fortalecer a estabilidade das leis; de acordo com Rousseau, propõe a criacão de instituições da Antiguidade Clássica: tribunado. censores, ditadura ocasional, religião civil, sistema de educação pública. Vide Parker, pp. 121-122.

Saint-Just, Ocuvres choisies, pp. 358-360 admite a necessidade de um ditador em toda a revolução, para salvar o Estado pela força, e de censores para o salvar pela virtude. Por isso, propõe a criação destes últimos - que devem ser anciãos com mais de sessenta anos - com a finalidade de censurarem a vida privada e a vida dos funcionários (Ob. cit., pp. 328, 340-341, 353-354).

A ditadura, tal como na Roma antiga, apresenta-se como um estado de excepção que, perante $v \mathrm{~m}$ perigo de índole militar ou civil, revoga temporariamente os direitos e liberdades constitucionais. Sobre a ditadura dırante a Revolução Francesa e sua relação com a Roma antiga vide $\mathrm{Cl}$. Nicolet, L'idée républicaine en France. Essai d'histoire critique, Paris, 1982, pp. 101-105.

(47) Vide Guillaume, Procès-verbaux I, pp. 227-235 (para o projecto de Rabaut); I, pp. 558-559; II, pp. XVI-XXV, XXVIII, XLIII, 31$-66,88,89,90,157,158-194,197-213,231,238$ (para o de Lepeletier); I, pp. 645-671 (para o de Deleyre); II, pp. LI-LV, 753-760 (para o de Chénier); I, pp. 496, 567-578 e II, pp. 25-27 (para o de Sieyès).

$\mathrm{O}$ texto de Rabaut vem reproduzido em P. Kessel, Les gauchistes de 89 cit., pp. 156-160; o de Lepeletier nas pp. 116-145. 
Tratarei mais adiante da semelhança de algumas das propostas destes projectos com o sistema de educação espartana. Agora vou apenas fazer uma alusão breve aos festivais públicos e ao papel dos exercícios físicos. Rabaut propõe uma educação comum de índole física e militar que oferece algumas semelhanças com as de Esparta. Começa por fazer a distinção entre instrução pública e educação nacional - a primeira esclarece, exercita o espírito e transmite conhecimentos, enquanto a segunda forma o coração e concede a virtude - e considera que, para pôr em prática a educação nacional, são necessários espaços livres, ginásios, jogos públicos, festivais nacionais, concursos fraternos entre todas as idades e ambos os sexos. Em sua opinião deve olhar-se para as práticas dos povos gregos, «surtout de ces Spartiates qui passaient leurs jours dans une société continuelle, et dont toute la vie était une apprentissage et un exercice de toutes les vertus». Quando pensa na possibilidade ou meios de aplicar algo dessas instituições da Antiguidade à França sente-se, contudo, desanimado, já que as diferenças são tantas que não permitem erguer os olhos para tão alto $\left({ }^{48}\right)$.

Marie-Joseph Chénier propõe também uma instrução pública em que os exercícios físicos, os jogos e festivais nacionais têm papel fundamental. Distingue na educação a parte do ensino, a moral e a física. Na primeira critica a educação existente e proclama a necessidade de a modificar desde a base. Quanto à educação moral, considera que o primeiro caminho para ela é o estabelecimento dos festivais nacionais de que a liberdade será a alma, e os prémios ramos de carvalho. A educação física - «appelée gymnastique dans les républiques de la Grèce», lembra Chénier - deve consistir de jogos e de exercícios do corpo e ser praticada pelas crianças, pelos adolescentes e também pelos adultos. Embora considere que não se deve tentar aplicar as instituições de cretenses e espartanos, como pretendem muitos, por não serem adequadas à França, nem propor «des romans politiques, faiblement échafaudés d'après la république de Platon, ou d'après les romans historiques composés sur Lacédémone», o seu projecto de festivais nacionais, com jogos e exercícios físicos, tem com muita probabilidade subjacente os grandes festivais helénicos. Não se esquece mesmo de lembrar que foi graças aos festivais, aos jogos e ao hábito da ginástica que Atenas, em século e meio, produziu tão grande número de homens célebres ${ }^{\left({ }^{49}\right)}$.

(48) Cf. Guillaume, Procès-verbaux I, pp. 231-235 (citacão da p. 233) $=$ Kessel, Les gauchistas de 89 cit., pp. 156-160 (cit. da p. 158).

(49) Cf. Guillaume, Procès-verbaux II, pp. 753, 754, 756, 758 e 759. Citaçōes das pp. 754 e 756.

Sobre as festas públicas que procuravam imitar as festas e gran- 
2. A identificação da camada dirigente com a Grécia e Roma, motivada por uma convivência assídua desde os bancos da escola com os autores e a história da Antiguidade Clássica, origina referências múltiplas quer a uma sociedade quer a outra. As alusões a factos e figuras de Roma são, no entanto, estatisticamente mais numerosas: os revolucionários, como vimos, estudaram quase só autores latinos e não tinham, de modo geral, com raras excepções, uma cultura grega directa sólida $\left({ }^{50}\right)$.

Ao contrário dos alemães seus contemporâneos que, sobretudo a partir de Winckelmann, dirigiam a sua atenção em especial para a Hélade, o culto dos revolucionários pela Antiguidade tem por centro Roma; a Grécia e seus valores são, regra geral, vistos por fontes romanas ou romanizadas ${ }^{(51)}$. Nesse sentido a Revolução Francesa pode considerar-se mais romana do que grega. Com toda a naturalidade, os inimigos da Revolução, e qualquer adversário político, aparecem comparados a Catilina ou com esse nome apelidados ${ }^{(52)}$. O nome de Bruto é dado a várias povoações e a considerável número de recém-nascidos.

A cidade de Ris pede que, em vez de Saint-Blaise, seja Bruto o seu padroeiro - nome que outras cidades e povoações também perfilharam $\left.{ }^{53}\right)$. Babeuf adopta os nomes de Camilo

des festivais da Antiguidade Clássica, sobretudo os gregos, vide Diaz-Plaja, pp. 113-126.

(50) Desmoulins parece ter sido o único que possvía uma sólida cultura grega directa. Vide Parker, pp. 85-92; Vidal-Naquet, pp. 21-22. Nos currículos de estudos dos Collèges frequentados pelos fut:ros revolucionários, na quase totalidade deles, apenas eram estudados autores latinos.

Os autores gregos citados, para além de Plutarco referido na nota 12, são Platão por sete vezes; Homero, Aristóteles e Políbio, por três vezes cada um; Píndaro, Demóstenes, Teofrasto, duas vezes; Heraclito, Heródoto, Eurípides, Epicteto, Pausânias, uma vez apenas.

Sobre os livros de autores gregos e latinos lidos e citados pelos homens da Revolução vide Parker, pp. 8-36.

(51) Vide Parker, p. 20.

(52) Vide Diaz-Plaja, pp. 49, 51 e $56-57$ e supra nota 43.

(53) Le Moniteur, n. 42 (2 de Nov. de 1793), p. 134 (ap:d Parker, p. 141); Sylvain Maréchal, Révolutions de Paris, n. 215, in P. Kessel, Les gauchistes de 89 cit., p. 186.

Bruto foi um dos nomes sagrados da Revolução: o seu amor à liberdade e à república era tomado como modelo e obiecto de emulação. No período da Convenção, de acordo com os registos da Conservatória do Sena, em quatrocentos recém-nascidos que receberam nomes gregos, romanos oy de mártires da Revolução havia trezentos com o nome de Bruto. Bruto, juntamente com outros, antigos e modernos - como Licurgo, Sólon, Aristides, Sócrates, Fócion, Catão, Camilo, Cincinato. Cévola, Marat, Lepeletier - foi objecto de verdadeiro culto. 0 vadre Fouché vai mesmo ao ponto de celebrar em 22 de Setembro de 1793 uma Fête de Brutus na Catedral de Nevers com descerramento de 
e Gaio Graco como prenomes seus, em substituição dos que possuía ${ }^{(54)}$. Como em Roma também em França, a seguir à República, veio uma ditadura militar que nasce de um regime com um nome revelador - «Consulado» $\left({ }^{55}\right)$, a Constituição de 1795 entrega a competência legislativa a dois conselhos com o significativo nome de Conselho dos Quinhentos e Conselho dos Anciãos ( $\left.{ }^{56}\right)$.

Se a identificação dos homens da Revolução é maior com a cultura romana do que com a grega, a respeito desta manifestam maior preferência por Esparta do que por Atenas $\left({ }^{57}\right)$. A cidade de Péricles, com raríssimas excepções de que C. Desmoulins é um exemplo, concita críticas e não elogios.

E significativa a afirmação de Billaud-Varenne em 20 de Abril de 1794, na sua comunicação sobre a «Teoria do governo democrático», de que a inflexível austeridade de Licurgo se torna em Esparta a base inquebrantável da república, enquanto em Atenas o carácter fraco e confiante de Sólon mergulha a cidade na escravatura. Esse paralelo, em sua opinião, encerra toda a ciência do governo. Por isso, como fizera Licurgo em Esparta, «il faut, pour ainsi dire, recréer le peuple qu'on veut rendre à la liberté». Por esse método se conseguirá a regeneração rápida $\left({ }^{58}\right)$.

Para Robespierre o espírito oportunista de Sólon deve ser evitado e são elucidativas da sua estima por Esparta as palavras que profere na sua grande comunicação de 7 de Maio de 1794, na qual, a determinado ponto, considera que o crime e a tirania campeiam na terra através dos tempos, onde a liberdade e a virtude repousam apenas por instantes sobre alguns pontos do globo. Um desses pontos, momento único na história, é Esparta que «brilha como um clarão nas trevas imensas» $\left.{ }^{59}\right)$.

um busto. Cf. J. Guillaume, Procès-verbaux, II, p. LXXXVIII; P. Kessel, Les gauchistes de 89 cit., p. 178. Sobre o assunto vide Parker, pp. 139$-140,144$ e 146-147.

(54) Babeuf justifica essa adopção em Tribun du Peuple, n. 23 , p. 1, nota 1 (apud Parker, p. 141). Vide ainda Diaz-Plaja, p. 131.

(55) Vide Diaz-Plaja, pp. 21-22; L. Bertrand, La fin du classicisme et le retour à l'antique, pp. 322, 328: N. Rouland, Rome, démocratie im possible?, Actes du Sud, 1981, p. 280.

(56) Vide Diaz-Plaja, p. 32.

(57) Vide Parker, passim; Diaz-Plaja, passim; Vidal-Naquet, p. 28. Rawson, pp. 268 e ss. coloca dúvidas a essa atracção predominante por Esparta.

(58) Citação de Le Moniteur, n. 212 (Abril 21, 1794), 264 (apud Vidal-Naquet, p. 29; N. Rouland, Rome, démocratie impossible?, p. 281, Diaz-Plaia, p. 72).

(59) La revolución jacobina, p. 158. Robespierre no inverno de 1792 e 1793 censura como ridículos os festivais públicos e a educação 
Saint-Just, por sua vez, observa que «les démocraties anciennes n'avaient pas de loi positive», adquiriam o apogeu da glória por meio das armas; mas quando «le peuple était assemblé, le gouvernement n'avait plus de forme absolue, tout se mouvait au gré des harangues» $\left({ }^{80}\right)$.

Para estes membros da Convenção - sobretudo para Saint-Just - , o ideal era a virtude severa das antigas Grécia e Roma, em especial de Esparta - uma virtude concebida segundo o modelo de Plutarco, composta de austeridade, simplicidade, doação, caridade, incorruptibilidade e devoção à pátria $\left({ }^{61}\right)$. Lembrando que foi graças à sua severidade que Licurgo impôs as reformas, Saint-Just é de opinião que pelo mesmo método se pode conseguir a regeneração rápida de França; para isso advoga a criação de instituições que possam refrear o procedimento dos renitentes e incorrigíveis $\left({ }^{(2)}\right)$. $O$ facto de Saint-Just ser membro da ditadura jacobina do Comité de Salvação Pública e de acreditar no poder do legislador induziu-o a sentir-se livre de ousar e de fazer a regeneração do seu país. Por inspiração do que se passara na Antiguidade Clássica e em consonância com outros revolucionários, queria organizar na França um sistema de festivais públicos, estabelecer censores já de idade, para censurar, se necessário, a vida privada dos jovens e dos comandantes do exército, e em especial a instauração de um regime educacional modelado pelo de Esparta $\left(^{(3)}\right)$. A compa-

de tipo espartano (vide Parker, p. 161), propostos em 1792 e 1793 ao Comité de Instrução Pública. No entanto, além de conhecer com toda a probabilidade os projectos de Saint-Just, em 1793 defendera o projecto de Lepeletier que, no essencial, não difere muito das propostas de Saint-Just e, em Maio, no discurso acima citado, adopta e desenvolve o projecto do Comité de Instrução Pública sobre os Festivais públicos propostos por Rabaud e Chénier. Vide Guillaume, Procès-verbaux II, pp. 3461 .

(80) L'esprit de la Révolution suivi de fragments sur les Institutions républicaines (éd. R. Mandrou), Paris, "Coll. 10/18», 1963, pp. 35-36 (apud Vidal-Naquet, p. 29; Rouland, Rome, démocratie impossible?, p. 281).

(61) Saint-Just admirava a existência dessa virtude no passado e nos heróis da Antiguidade Clássica e lamentava a sua falta na França do seu tempo. Vide Parker, pp. 152-155. Essa virtude é exaltada em livros, discursos, folhetos, cartas, panfletos, nos quais o recurso aos modelos da Grécia e de Roma é prática comum. Vide Diaz-Plaja, pp. 69-74.

(62) Cf. Fragments sur les institutions republicaines, in Oeuvres choisies cit., pp. 327-329.

(63) O essencial das ideias de Saint-Just sobre tais matériasfestivais públicos, censores, educação - encontram-se na obra póstuma e incompleta a que se costuma dar o título de Instituições Republicanas e que, pelo seu carácter fragmentado, será melhor designar por 
ração dos passos da Vida de Licurgo de Plutarco (16-20) com o projecto de Saint-Just deixa bem claras as coincidências e mostra até que ponto ele é devedor de Esparta. Como essa pólis grega, Saint-Just pretendia que em França os jovens do sexo masculino fossem educados até aos dezasseis anos pelo Estado $\left({ }^{64}\right)$, incentivados no amor ao silêncio e ao laconismo; que, reunidos em companhias, vivessem em comunidade, dormindo em esteiras de palha, e em grupo tomassem as refeições, constituídas por frutos, vegetais e leite; que os professores escolhessem para chefes os de melhor conduta $\left.{ }^{65}\right)$. Saint-Just parece até propor algo que se aproxima da pederastia espartana $\left({ }^{(86)}\right.$.

A educação era um tema que ocupava o espírito de muitos revolucionários e foi objecto de aceso debate na Convenção Nacional, desde o Inverno de 1792 até ao Verão de 1793, com vários projectos a darem entrada no Comité de Instrução Pública. Discutiu-se com calor acerca da aplicabilidade ou não aplicabilidade à França revolucionária das normas e princípios educativos de Esparta. O plano de Lepeletier e o projecto de Robespierre, quase uma reprodução do anterior, apresentam propostas próximas das de Saint-Just e encontram-se de certo modo imbuídos do espírito da educação espartana $\left({ }^{87}\right)$ : distinguem entre educação, que forma o homem, e instrução, que transmite conhecimentos, e estabelecem a educação comunitária

Fragmentos sobre as Instituições Republicanas. Cf. Fragmentos, in Oeuvres choisies cit., pp. 350-352 (para os festivais públicos), 352-354 (para os censores) e 341-344 (para a educação).

(64) Em Esparta esse tipo de educação iniciava-se aos sete anos, no projecto de Saint-Just aos cinco. Cf. Plutarco, Licurgo 16.7; Saint.Just, Oeuvres choisies cit., p. 341.

(65) Saint-Just, ob. cit., pp. 342-343, no entanto, ao contrário de Esparta - que proibia que os cidadãos, os "Iguais», se dedicassem a qualquer ocıpação que não fosse a guerra e a preparação para ela - queria que todos aprendessem a agricultura e o comércio. Para a proibição de os cidadãos espartanos se dedicarem a qualquer actividade económica vide Xenfonte, República dos Lacedemónios, 7.

(68) Cf. Plutarco, Lyc. 17.1 e 18.8 e 9; Saint-Just, Fragments, in Oeuvres choisies cit., p. 344.

(67) O plano de Lepeletier foi lido à Convenção por Robespierre e aí por ele defendido em 13 de Jilho de 1793, mas talvez tenha sido redigido em fins de Dezembro ro ano anterior (vide Guillaume, Procèsverbaux II, pp. XVI-XVII; Kessel, Les gauchistes de 89 cit., p. 115). Aprovado o plano na generalidade em 13 de Agosto, a redacção definitiva retira-lhe o carácter de obrigatoriedade do envio das crianças pelos pais para os estabelecimentos nacionais então criados, o que origina vários protestos (vide Guillaume, Procès-verbaux II, p. 280; Kessel, ob. cit., pp. 151-153). O projecto de Robespierre foi apresentado em nome do Comité de Instrução Pública em 29 de Julho de 1793. Vide Guillaume, Procès-verbaux II, pp. 161-170. 
a expensas do Estado. Essa educação será ministrada nas chamadas «maisons d'éducation», cuja direcção estará entregue a anciãos. Entre os cinco e os doze anos, para os rapazes, e entre os cinco e os onze, para as raparigas, os jovens vivem, dormem, tomam as refeições e exercitam-se em comum, divididos em formações de 50, entregues a um instrutor, e agrupados de modo que os mais novos estivessem sob a vigilância dos mais velhos. A alimentação será frugal, o vestuário grosseiro; para além de se iniciarem em diversos trabalhos, farão exercícios físicos e receberão instrução e treino de manejamento de armas.

Com tal sistema de educação visa-se «fortificar o corpo, desenvolvê-lo pelos exercícios de ginástica; acostumar os jovens ao trabalho manual, endurecê-los em toda a espécie de fadiga, submetê-los ao jogo de uma disciplina salutar» $\left({ }^{68}\right)$.

Estes projectos de educação foram feitos com o pensamento no modelo de Esparta, já que muitas das normas e práticas neles propostas, como aliás acontecia em Saint-Just, apresentam significativo paralelismo com o que aí se verificava. Aliás o próprio Lepeletier, no texto que introduz e explica o plano, confirma que tinha em sua mente o sistema espartano, quando redigia esse plano. Considera que seria um belo sonho prolongar esse tipo de educação até ao fim da adolescência e sublinha que «quelquefois nous l'avons rêvé délicieusement avec Platon; quelquefois nous l'avons lu avec enthousiasme, realisé dans les fastes de Lacédémone». Acrescenta, no entanto, que «Platon ne faisait que des philosophes, Lycurgue ne faisait que des soldats» e que a República francesa, cujo esplendor residia no comércio e na agricultura, necessitava de formar pessoas de todas as profissões $\left(^{69}\right)$.

O débito a Esparta foi também sentido pelos contemporâneos, quer pelos apoiantes do plano quer pelos críticos. Entre estes o Padre Grégoire, em discurso proferido a esse propósito na Convenção em 30 de Julho de 1793, considera não ser suficiente que um sistema educativo se apresente escoltado de nomes ilustres, que tenha por patronos Minos, Platão, Licurgo e Lepeletier, mas é preciso ter em conta a diferença enorme existente entre Esparta e a França $\left({ }^{70}\right)$. Não menos significativo é um passo das suas Memórias que, ao referir-se à educação comunitária proposta nos textos de Lepeletier e Robes-

(68) Cf. Guillaume, Procès-verbaux II, pp. 55 e 162 (=P. Kessel, Les gauchistes de 89 cit., p. 136, para o de Lepeletier).

(69) Cf. Guillaume, Procès-verbaux II, p. 39 (=P. Kessel, Les gauchistes de 89 cit., p. 123).

(70) Oeuvres de l'Abbé Grégoire, avant-propos por A. Soboul, Liechenstein, 1977, tome II, p. 30 (=Guillaume, Procès-verbaux II, p. 173). 


\section{Revista de História das Ideias}

pierre - Grégoire chama-lhe «éducation communale» -, escreve: «on faisait de la France une nouvelle Sparte, et appliquant à trente millions d'hommes le régime d'une petite ville de la Grèce, tous les enfants devaient être enlevès à leurs parents et parqués dans des écoles» $\left({ }^{\mathbf{7 1}}\right)$.

A influência espartana não deve ser alheia ainda às doutrinas igualitárias que, em maior ou menor grau, estão presentes nas páginas, discursos e actividade de boa parte dos revolucionários. Se bem que estes as pudessem encontrar nas obras de autores da «época das luzes» - especialmente em Rousseau -, a inspiração de tais ideias vinha também da acção de Licurgo e dos Gracos e o modelo era-lhes sugerido pelo regime de propriedade de Esparta - a cidade dos «Iguais», dos Homoioi -, onde cada cidadão, na época áurea, possuía uma parcela de terra inalienável, o clêros, equivalente ao dos outros em valor e volume da colheita $\left({ }^{72}\right)$. Era natural, portanto, que Esparta aparecesse como o modelo mais apropriado para aqueles que, movidos pelo desejo de ver uma menor dissimetria entre os Franceses, vão à Antiguidade Clássica procurar argumentos tendentes a provar que, como a república e a igualdade trouxeram felicidade nesse passado distante, também a podem oferecer agora e no futuro.

As ideias igualitárias, que encontram forte incentivo nas obras de J.-J. Rousseau constantemente citado, estão na altura bastante espalhadas, mesmo antes de 1789, mas sobretudo nos anos em que vigora a Convenção $\left({ }^{73}\right)$. São vários os Revolucionários que se pronunciam pela necessidade de uma lei agrária, entendida então como a colocação em comum de todas as terras, para depois se proceder a uma partilha igual entre as famílias, ou como a socialização das terras das comunidades religiosas com a sua entrega aos trabalhadores que não tivessem propriedade, ou ainda como a partilha igual do território das comunas entre todas as famílias $\left({ }^{74}\right)$. Dos intervenientes cito,

(71) Mémoires I, p. 344 (=Guillaume, Procès-verbaux II, p. 178).

(72) Cf. Heródoto 7.234; Aristóteles, Pol., 1269 a 29 e ss.; Plutarco, Lyc. 8. Sobre o assunto vide P. Oliva, Sparta and her social problems, Amsterdam, 1971, cap. 4; J.T. Hooker, The Ancient Spartans, London, 1980 , p. 133 .

(73) Citam-no, por exemplo, referindo-se em especial ao Contrato Social, o Padre Cournant, De la propriété ou la cause du pauvre, Paris, 1791 (apud P. Kessel, Les gauchistes de 89 cit., p. 49 nota 1); o Padre $\mathrm{Cl}$. Fauchet, num discurso à Assemblée de la Confédération universelle des Amis de la Vérité, no qual chama "sublime Rousseau» e apresenta vm projecto de declaração de direitos do homem inspirado nas suas ideias (in Kessel, ob. cit., pp. 51, 52, 56 e 60).

(74) Vide Kessel, Les gauchistes de 89 cit., pp. 43-106, onde se 
entre outros, Babeuf, Saint-Just, Robespierre, Marat, o Padre Cl. Fauchet, o Padre Cournand, Sylvain Maréchal, Mamoro, Rabaut, Varlet, Harmand. De modo geral consideram que a desigualdade de fortunas é uma injustiça e deriva de processos ilícitos que não hesitam em classificar de roubo $\left({ }^{75}\right)$. Para eles, um direito da natureza humana, que se adquire com a vida, reside na posse de bens suficientes para prover à subsistência própria e à da família. Se os homens não os possuem, esse direito natural autoriza-os a apoderar-se dos daqueles que têm em excesso $\left(^{76}\right)$. Consideravam a igualdade a alma da república e o que melhor caracteriza a democracia. Pensam no entanto que só a igualdade política não basta, porque logo os pobres a sentem enfraquecida pela desigualdade de fortunas. Isto é: à igualdade política tem de corresponder, o mais possível, a igualdade das terras. Daí que defendam a sua partilha, apresentem soluções diversas nesse sentido e solicitem aos legisladores a promulgação de leis que concedam à França uma distribuição mais equitativa desses haveres $\left({ }^{77}\right)$.

coligem vários textos e tomadas de posição a respeito da lei agrária e dos direitos do homem.

(75) Babeuf considera os códigos instrumentos que «legitimam» a pilhagem das terras (in M. Dommaget, Babeuf et la conjuration des Egaux, Paris, s.d., p. 7).

Esta posição recorda de imediato a expressão violenta de Sólon para classificar a apropriação de terras pelos nobres na Atenas do séc. VII: que os nobres "roubaram a saque», sem poupar os templos e o dêmos (fr. 4 West, vv. 12-13).

(76) Cf. Fauchet, in Kessel, Les gauchistes de 89 cit., pp. 51, 57, 58; Cl. Romieux, Les elements du contrat social, Paris, 1792 (apud Kessel, $o b$. cit., p. 74), que distingue a propriedade directa - o direito exclusivo de posse de acordo com a lei - da propriedade indirecta, o direito que todo o homem, incapaz de prover às necessidades, tem sobre os bens de outrem; J.P. Marat, La constitution, ou Projet de déclaration, Paris, 1789 (apud Kessel, ob. cit., pp. 67 e 69) considera que os homens, tendo recebido os mesmos direitos da natureza devem conservar direitos iguais no estado social, entre os quais a propriedade de bens, e que o cidadão honesto, abandonado pela sociedade à sua miséria e desespero, entra no estado de natureza e tem o direito de reivindicar as vantagens que não pode alienar, senão para conseguir outras melhores; toda a autoridade que se lhe opõe é tirânica, assassino o juiz que o condena à morte. Para Saint-Just, Fragments, in Oeuvres choisies cit., p. 337, a opulência é uma infâmia e não devem existir ricos e pobres. $\mathrm{O}$ homem deve ter uma vida independente. Para isso, considera necessário dar terras a todos.

(77) Entre outros, Marat, ob. cit., na nota anterior, pp. 68-69 considera que não deve existir desigualdade nas fortunas, senão a que resulta da desigualdade das faculdades naturais; mesmo para essa, a lei deve fixar os limites que não deve franquear. Em sua opinião, os ricos gozam uma vida larga, enquanto os pobres, graças a cujo trabalho se formam as fortunas, têm uma vida de privações. Pensa por isso 
Embora ponham mais a tónica na lição da natureza do que em outros modelos, os igualitários foram colher muitas das suas ideias, quer directamente quer através de obras de autores da «época das luzes» (sobretudo Rousseau), em Licurgo e Esparta, no chamado código de Minos, em Platão e nas leis agrárias de Roma, e utilizavam esses nomes para dar às suas ideias um ar de prestígio e de exequibilidade $\left({ }^{78}\right)$. Rabaut, em apoio da sua teoria relativa à publicação de leis que definissem um quantitativo máximo de fortuna que cada homem devia possuir, lembra o exemplo de Atenas, de governo democrático, onde as fortunas, até determinado quantitativo, estavam isentas de qualquer ónus; mas, para além desse montante, os bens, considerados supérfluos, eram onerados com uma taxa que aumentava proporcionalmente aos haveres $\left({ }^{79}\right)$. Trata-se naturalmente de uma alusão às conhecidas «liturgias» atenienses: os cidadãos com mais posses eram obrigados a subsidiar a manutenção de barcos de guerra, a libertação de prisioneiros e o ensaio de coros e peças de teatro concorrentes às Grandes Dionísias $\left({ }^{80}\right)$. Sylvain Maréchal, em propaganda de ideias que estiveram na base da «Conjura dos Iguais», compõe uma canção em que se evocam os Gracos, Publícola, Bruto ${ }^{\left({ }^{81}\right)}$. Babeuf, que se distin-

que, por exigência da justiça, pelo menos uma parte dos bens dos prıvilegiados deve ser repartıda entre os cidadãos a que tudo falta. J.-P. Rabaut, "De l'égalité» II e II, Chronique de Paris de 19 e de 21 de Janeiro de 1793 (apud Kessel, ob. cit., pp. 75-81, pensa que a igualdade política deve ser completada com a igualdade de facto: propõe uma partilha de terras o mas equitativa possível e aconselha o legislador a criar leis que estipulem o máximo de fortuna que um homem pode possuir. Vide ainda o discurso do deputado Harmand publicado no Journal Universel n. 1250, de 26 de Abril de 1793 (apud Kessel, ob. cit., pp. 92-99).

(78) Fauchet, ob. cit., na nota 73, p. 57, por exemplo, considera que o modelo não está na antiga Grécia ou antiga Itália: em Esparta que repartiu as terras por um pequeno número de famílias - as únicas consideradas com direito de cidadania - e reduziu à escravatura os vencidos, ou em Roma que fazia a cada passo partilhas iguais de terras e as refazia para ceder à violência das classes populares empobrecidas, não cessando de ultrajar a natureza. Para ele o modelo encontrava-se ná natureza imutável (p. 58).

(79) "De l'égalité III", in Kessel, Les Gauchistes de 89 cit., p. 80.

(80) Sobre "liturgias» em Atenas vide N. Lewis, "Leitourgia and Related Terms», GRBS 3 (1960) 175-184.

(81) Cf. M. Dommaget, Babeuf et la Conjuration des Egaux cit., pp. 29-30. A estrofe em questão é a seguinte

Evoque l'ombre des Gracchus

Des Publicola, des Brutus;

Qu'ils te servent d'enceinte!

Tribun courageux, hâte-toi,

Nous t'attendons: trace la loi

De l'Egalité Sainte. 
gue nessa faç̧ão, considera que só a posse igualitária da propriedade seria capaz de afastar a miséria da maioria do povo e liderará a «Conjura dos Iguais» que agrupa destacados Revolucionários escapados ao 9 Termidor. O código de Licurgo e as leis agrárias dos Gracos tornaram-se para ele em modelos que queria ver imitados pela França $\left.{ }^{82}\right)$. Elucidativa é ainda a opinião do Padre Cournand de que o exemplo de Licurgo prova ser a igualdade de fortuna a via mais segura para a organização de uma sociedade em que todos os homens sejam bons e felizes $\left(^{83}\right)$.

Esta afirmação relaciona-se com outra característica que, na esteira dos homens da «época das luzes», marca o culto da camada dirigente da Revolução pela Grécia, ou até pela Antiguidade em geral: o fascínio que sobre eles exercia o legislador. Enchem com os seus nomes as sessões das assembleias revolucionárias e colocam as suas estátuas na sala de reuniões da Convenção ${ }^{84}$ ). O legislador é considerado uma figura semimítica, uma espécie de herói cultural que opera a passagem quer da barbárie à civilização, quer da anarquia primitiva aos inícios do Estado ${ }^{85}$ ). Trata-se de uma visão sobrevalorizada,

(82) Tomou mesmo para si o nome de Gaio Graco em substituição dos seus prenomes cristãos (vide supra nota 54).

$\mathrm{Na}$ "Conjura dos Iguais» estiveram implicados, além de outros, Babeuf, Buonarroti, Sylvain Maréchal, Félix Lepeletier, Darthé, Charles Germain, A.-M. Bertrand, Antonelle, Didier, Debon, Clémence. Sobre o assunto e sobre o papel de Babeuf vide Buonarroti, Conspiration Pour l'égalité, préface par G. Lefebvre, Paris, 1957; M. Dommaget, Babeuf et la Conjuration des Egaux, Paris, s.d. Sobre a actividade de Babeuf depois do Termidor vide ainda Rawson, p. 289.

(83) Padre Cournand, De la propriété ou la cause du pauvre, Paris, 1791, pp. $44-45$ (apud Parker, p. 113). Vide ainda Bonneville (De l'esprit des religions, Paris, 1791, I, pp. 52-54 e 77; II, pp. 25 e 82); Boissel, Le catéchisme du genre humain, 1789, pp. 56, 122-123: a igualdade de propriedade traz poder, virtude e felicidade aos Estados, segundo o primeiro, e promove a riqueza e bane a avareza, a cupidez e o luxo corrupto, para o segundo. Para Billaud-Varenne a lgualdade de riqueza deve ser conseguida não pela igual divisão da propriedade, que seria impossível e quimérica mas através de leis que distribuissem as grandes heranças aos pobres. Tal reforma, embora radical, teria o mérito de não produzir uma súbita e convulsiva alteração que originaria a oposição de todos e tornaria os esforços do legislador infrutíferos - como o demonstram Lisandro e Ágis em Esparta, Sólon em Atenas e os Gracos em Roma -, expondo-o ao perigo do assassínio. Apud Kessel, Les Gauchistes de 89 cit., pp. 46-51.

(84) As estátuas dos legisladores na sala da Convenção Nacional, já me referi no início deste trabalho.

(85) Cf. Jancourt, "Lacédémone, république de», in Encyclopedie (1767) vol. IX, 124a-130b. 
mas que reconhece o papel decisivo dos legisladores gregos na evolução e desenvolvimento da pólis $\left({ }^{86}\right)$.

Este retrato idealizado do legislador grego, por parte dos Revolucionários, deixa perceber o desejo de também eles próprios exercerem em França um papel idêntico ao desempenhado por esses homens na Grécia. Como escreve M. Abensour, a Revolução abre «une carrière nouvelle, celle de législateur», a grande número de intelectuais, vindos da burguesia ou da pequena burguesia, na maior parte formados em leis $\left({ }^{87}\right)$.

Saint-Just sente-se o herdeiro do legislador grego e encarna o seu espírito. Na obra Esprit de la Révolution - numa manifestação de fé nas instituições e no seu criador - solicita aos legisladores que dotem a França de leis capazes de forçarem os cidadãos a amarem as virtudes que ele admirava na Antiguidade Clássica. Saint-Just sente-se imbuído desta fé, exalta Licurgo e a igualdade por ele instituída e acreditava possuir, como ele, também o poder para imprimir à França as reformas necessárias $\left({ }^{\mathbf{8 8}}\right)$.

Dentre os vários legisladores gregos, Licurgo é o preferido e o mais citado. $\mathrm{E}$ hoje afinal nem sequer se tem a certeza da sua existência real. Vêem nele o legislador por excelência - o «legislador da Grécia inteira» como escreve Jancourt ( ${ }^{89}$ ).

Para os Revolucionários franceses, como Esparta se transforma no símbolo da cidade regenerada, Licurgo oferece o exemplo a seguir para realizar essa regeneração. $\mathbf{E}$ afinal o que diz Rousseau no Discurso sobre a Origem da Desigualdade, ao considerar que os legisladores, para evitar que o Estado seja obra do acaso, devem «commencer par nettoyer l'aire et écarter tous les vieux matériaux, comme fit Lycurgue à Sparte pour élever ensuite un bon édifice» $\left({ }^{90}\right)$.

(86) Sobre o papel e importância dos legisladores no desenvolvimento da pólis vide W.G. Forrest, La Naissance de la démocratie grecque (trad. franc.), Paris, 1966, pp. 143-145; L.H. Jeffery, Archaic Greece, London, 1976 pp. 42-44; A. Snodgrass, Archaic Greece. The Age of Experiment, London, 1980, pp. 118-120; Cl. Mossé, La Grèce archaïque d'Homère à Eschyle, Paris, 1984, pp. 115-129. 1968, p. 239.

(87) Actes du Colloque Saint-Just (Sorbonne, 25 Juin 1967), Paris,

(88) Oeuvres Complètes I, pp. 282, 283, 287, 291, 292 e $422-423$. Os Fragments, com a sua gerontocracia institucional, surgem como uma versão das leis de Platão (L'esprit de la Révolution suivi des fragments sur Les Institutions republicaines (éd. R. Mandrou), Paris, 1963, pp. 168-170 (apud Vidal-Naquet, p. 30)=Oeuvres choisies cit., pp. 352-354. Vide supra nota 46.

(89) Artigo citado na nota 85.

(90) Oeuvres complètes III, Coll. Pléiade, Paris, 1966, p. 180. Neste texto de Rousseau está implícito o conceito de que Licurgo fez 
3. A crítica a Esparta é rara, como são escassos os elogios a Atenas. Encontramos essa crítica nos oradores da «Planície» e nos jacobinos moderados, quer o façam por recusa do ascetismo de Esparta, quer em nome da França real. Para Duhem, Esparta «était un convent, une abbaye de moines» $\left({ }^{91}\right)$. Lepeletier por sua vez, apesar de admirar Esparta e de redigir um plano de educação que apresenta semelhanças com o sistema daquela pólis, lamenta que as leis de Licurgo apenas produzissem soldados. Posição um tanto crítica é também a de Vergniaud $\left({ }^{92}\right)$.

Camille Desmoulins, em oposição quer ao girondino Brissot, quer a Robespierre e Saint-Just, associa a crítica a Esparta ao elogio de Atenas, considerando esta a cidade aberta aos talentos e à felicidade de viver, face ao igualitarismo de Esparta $\left({ }^{93}\right)$. A Brissot perguntará:

"que voulez-vous dire avec votre brouet noir et votre liberté de Lacédémone? Le beau législateur que ce Lycurgue dont la science n'a consisté qu'à imposer des privations à ses concitoyens; qui les a rendus égaux comme la tempête rend égaux tous ceux qui ont fait naufrage, comme Omar rendait tous les Musulmans égaux, et aussi savans les uns que les autres, en brûlant toutes les bibliothèques!» ( $\left.{ }^{94}\right)$.

A discussão entre os defensores de Atenas e os de Esparta adquire carácter ideológico durante o período do Terror e a oposição pode ser simbolizada em Desmoulins, liberal, que admira Sólon e Atenas, e Saint-Just, radical, que prefere Licurgo e Esparta. Em confronto estão afinal duas concepções de sociedade: uma, que tinha por modelo Atenas, põe a tónica na liberdade e na iniciativa e mérito individual; a outra, modelada por Esparta, dava realce à igualdade e ao interesse colectivo $\left.{ }^{95}\right)$. E afinal o ressurgir do debate, ao longo dos anos

tábua rasa do que existia em Esparta, partindo do nada, de que fala Platão, Leg. III, 684 d-e.

(91) Guillaume, Procès-Verbaux II, p. 674. Este era um tema já com defensores na "época das luzes» como foi o caso de Turgot, o Barão d'Holbach, Diderot. Sobre o assunto vide Rawson, pp. 257-258.

(92) Para a posição de Vergniaud vide Moniteur, 11 Maio 1793 (apud Diaz-Plaja, pp. 20-21).

(93) Cf. Le Vieux Cordelier, n.os 6 e 7 in Oeuvres X, éd. Soboul, München, 1980 , pp. 335 e ss. e 351 e ss. respectivamente. Vide Parker, pp. 75-78; Diaz-Plaja, pp. 24-26.

(94) Oeuvres X, p. 346.

(95) A discussão integra-se no chamado "processo dos indulgentes» que terminou com a condenação à morte e execução de Danton e Desmoulins, entre outros. Nessa discussão o recurso aos exemplos clássicos, quer por uns quer por outros, é constante. Vide Diaz-Plaja, pp. 61-63. 
repetido, que encontramos na Grécia, sobretudo nos séculos $\mathrm{V}$ $\varepsilon$ IV a. C., entre os admiradores do regime espartano e os defensores do sistema ateniense, ou seja entre oligarcas e democratas.

Desmoulins, amigo de Danton, ataca a tirania do Terror, comparando as suas crueldades às de Tibério, Nero e Calígula, e considera que a liberdade é necessária para manter a república. Em contrapartida, exalta os tempos felizes de liberdade em Atenas e pensa que as suas instituições seriam boas e úteis para a Europa. Aristófanes pode pôr em cena Cléon, criticá-lo e ridicularizá-lo, prova da «supériorité de la démocratie grecque» e da «liberté indéfinie du théâtre d'Athènes» $\left.{ }^{96}\right)$. Sólon - refere Desmoulins - é modelo de legislador e foi um dos Sete Sábios; para isso não teve de abandonar as alegrias da vida e os prazeres do dia a dia. Considera, por isso, os Atenienses, "verdadeiros republicanos, democratas permanentes por princípio e por instinto» $\left.{ }^{(97}\right)$. Não interessa uma igualdade impossível de bens, mas uma igualdade de direito e de felicidade ${ }^{98}$ ). Importante para Desmoulins era a liberdade política e individual do cidadão, sobretudo a liberdade e franqueza de expressão. O seu n. ${ }^{\circ} 7$ do Vieux Cordelier - com recurso constante a exemplos de Atenas e de Roma - é uma veemente e bela defesa dessa liberdade e ao mesmo tempo uma crítica sem tréguas à mordaça e à suspeição instituída pelo regime do Terror $\left({ }^{99}\right)$. Recorda que Roma também se chamava república no tempo de Augusto, Tibério e Cláudio e, no entanto, foi uma época considerada de extrema servidão, por ter sido banida a franqueza de expressão; cita a propósito a frase de Tácito omisso omni non solum loquendi, imo audiendi commercio. Em sua opinião essa franqueza é precisamente «l'ame des républiques, leur pouls, leur respiration...., le souffle auquel on reconnoît que la liberté vit encore» $\left({ }^{100}\right)$. Prefere assim a

(96) Le Vieux Cordelier, n. 7 , in Oeuvres X, p. 388. Aristófanes criticou Cléon em várias comédias: Acarnenses (sobretudo vv. 5 ss., 37.5 ss., 503 ss., 609 ss.), Os Cavaleiros (passim), As Vespas (passim), A Paz (passim). Vide Maria de Fátima de Sousa e Silva, Aristófanes: Os Cavaleiros, introdução, versão do grego e notas de...., Coimbra, 1985, pp. 23-26; Crítica do Teatro na Comédia Antiga, Coimbra, 1987, pp. 46$-51,76-82$ e $99-100$.

(97) Ibidem, pp. 377-381. Citação da p. 378.

(98) Ibidiem, pp. 367-368.

(99) Oeuvres X, pp. 351-398.

(100) Oeuvres X, pp. 357-359. Citação da p. 359. Tácito é dos autores mais referidos: 25 vezes. A citação, tal como aparece em Desmoulins, possivelmente não está correcta. Não a consegui detectar nas obras de Tácito, mas encontrei uma outra com o mesmo sentido em Agrícola 2: adempto... etiam loquendi audiendique commercio. 


\section{Grécia e Roma na Revolução Francesa}

intemperança de palavra da democracia e o pessimismo eterno dos seus detractores ao terror geral que cala todas as bocas em França ( $\left.{ }^{101}\right)$.

Esta crítica parece ter surtido algum efeito, já que o discurso "Sobre os princípios de moral política», de 5 de $\mathrm{Fe}-$ vereiro de 1794, sugere - como observa Vidal-Naquet (pp. 30-31, nota 75) - um Robespierre na defensiva. A determinada altura declara:

«nous ne prétendons point jeter la république française dans le monde de celle de Sparte; nous ne voulons lui donner ni l'austerité ni la corruption du cloître» (102).

A defesa da liberdade e concomitante crítica aos principais líderes da ditadura do Terror vai valer a Desmoulins a morte. E Camille Desmoulins que, com os seus ataques virulentos, terá dado, possivelmente, considerável contribuição para a condenação de Brissot e outros girondinos, morre afinal como digno defensor da construção de uma sociedade aberta e da liberdade de opinião.

Esta liberdade de expressão e franqueza de palavra constituía uma das principais características da democracia ateniense, a ponto de os cidadãos se gabarem da sua isegoria («igualdade no falar»), de par com a isonomia («igualdade nos direitos» ou perante a lei) e isocracia («igualdade no poder»). Demóstenes, Filípicas 3.3 podia dizer que essa franqueza constituía um direito de tal modo reconhecido na cidade que até o concediam aos escravos $\left({ }^{103}\right)$.

A predilecção de parte dos homens da Revolução, sobretudo dos mais radicais, por Esparta explica-se pela sua dependência da tradição que lhes transmitia uma visão da Grécia antiga bastante diferente da que hoje temos. Derivava ela de Xenofonte, Platão e outros oligarcas que, simpatizantes de Esparta, não sentiam inclinações pela democracia e acusavam

(101) Oeuvnes X, pp. 365-366.

(102) Le Moniteur, de 7 de Fev. 1794 (=La revolución jacobina, pp. 135-157). Citação colhida em Vidal-Naquet, pp. 30-31 nota 75.

(103) Para a isonomia, isegoria e isocracia vide $M$. Ostwald, Nomos and the Beginings of the Athenian Democracy. Oxford, 1969, pp. 96-136, 137, 146-147, 153-158 e 180-182; M.H. da Rocha Pereira, Estudos de História da Cultura Clássica: I - Cultura Grega, Lisboa, 1985 , p. 148 e nota 15; C. Hignett, A History of the Athenian Constitution to the end of the Fifth Century B.C., Oxford, 1952, repr. 1975, p. 157 e nota 6; J. Ribeiro Ferreira. "Aspectos políticos nas Suplicantes de Eurípides», Humanitas, $37-38$ (1985-1986), nota 27 e Aspectos da Democracia Grega, Coimbra, 1988, pp. 12-19. 
o governo do dêmos em Atenas de governo da ignorância, da incompetência e da anarquia; derivava ainda da antiga cultura retórica que se origina em Isócrates e no período helenístico. Essa tradição é aceite e transmitida ao longo dos tempos e enforma, com leves dissonâncias, a «época das luzes» ( $\left.{ }^{104}\right)$. Essa tradição, entre Esparta e Atenas, pende quase sempre para a primeira: cito o caso de Rollin, um jansenista que viveu entre 1661 e 1741, o padre Barthélemy e Rousseau ( ${ }^{(105)}$. Como não fazia a distinção entre história crítica e mito histórico-político, desconhecia Tucídides e estava familiarizada com Plutarco, Cícero e Tito Lívio $\left({ }^{108}\right)$, tal tradição era de modo geral hostil à democracia ateniense: Rollin critica-a; Barthélemy atribui a sua instituição a Teseu, como refere Plutarco, Teseu 24-25; o enciclopedista F. Turpin e o filósofo Mably falam de imprudência de Sólon, por ter abandonado as rédeas do poder nas mãos da populaça que usava a liberdade para prejudicar os seus concidadãos ${ }^{(107)}$. Mably, além disso, elege para seu herói Fócion - um estratego ateniense que o macedónio Antípatro coloca no poder, depois de desembaraçar Atenas da democracia em 322 a. C. - e afirma que «Phocion avait, dans Athènes corrompue, les moeurs simples et frugales de l'ancienne Lacédémone» $\left({ }^{108}\right)$.

Ao deparar com tais afirmações, imediatamente vem à memória a polémica travada em Atenas, na segunda metade

(104) Vide Vidal-Naquet pp. 22-26; Rawson, passim.

(105) J.J. Rousseau pensava escrever uma História da Lacedemónia que chegou a iniciar (Oeuvres Complètes, III, coll. Pléiade, Paris, 1966, pp. 544-548) e em 1752, na Dernière réponse aos adversários do Discours sur les sciences et les Arts, afirma: «L'embarras de mes adversaires est visible toutes les fois qu'il faut parler de Sparte» (Oeuvres complètes, III, cit., p. 83). Excepções a essa tendência filo-espartana são Voltaire e o barão d'Holbach. Vide Rawson, pp. 220-267.

(106) Vide Parker, p. 22.

(107) Rollin, Histoire Romaine depuis la fondation de Rome jusqu'à la bataille d'Atium, Paris, 1740, pp. 360-361; J.J. Barthélemey, Voyage du jeune Anacharsis, 1788, I, p. 25; F. Turpin, Histoire des anciennes républiques..., 1769 (apud Vidal-Naquet, p. 23). Vide ainda Volney, Oeuvres choisies, Paris, 1827, p. 81.

A idealização da ordem do regime e Esparta, como fruto das leis de Licurgo, em contraste com certa anarquia reinante em Atenas, devido à imprudência da legislação de Sólon, vem sublinhada por Mably nos livros I e II das Observations sur l'histoire de la Grèce, in Oeuvres complètes, Paris, 1798, tomo IV, pp. 1-76. As críticas à imprudência de Sólon encontram-se sobretudo nas pp. 40-42.

(108) Mably, Entretiens de Phocion sur le rapport de la morale avec la politique, in Oeuvres complètes, cit., X, p. 14. Para uma comparação entre Esparta e Atenas, pp. 7-10. 


\section{Grécia e Roma na Revolução Francesa}

do século V e no IV, entre os democratas e oligarcas, com os últimos a acusarem o governo do povo em Atenas de governo de ignorância, inccmpetência e anarquia $\left({ }^{109}\right)$ e a defenderem, cada vez mais insistentemente a partir dos últimos anos do século V, a instauração em Atenas de uma democracia limitada a que apelidavam patrios politeia, a «constituição dos antepassados», cuja origem uns atribuíam a Teseu, outros a Sólon e outros ainda a Clístenes $\left({ }^{110}\right)$.

Nesta concepção negativa da democracia ateniense, os homens da «época das luzes» e da Revolução são afinal os herdeiros de uma tradição antiga, onde a crítica à anarquia e corrupção da democracia ateniense se contrapõe muitas vezes a ideia de ordem, de eunomia e de «milagre espartano».

Depois do 9 Termidor (27 de Junho de 1794), a atracção pela Antiguidade Clássica esmorece um pouco. Como observa Parker (p. 178), os líderes do Termidor, desiludidos, não acreditavam na indispensabilidade da virtude e da regeneração; apenas pensavam em assegurar a «máquina» do governo.

A exaltação das virtudes da Antiguidade Clássica e o apelo à sua imitação, tinham estado intimamente associados ao período radicalista do Terror. Entram por isso em relativo descrédito, descrédito esse que atinge sobretudo certas manifestações extravagantes de interesse pela Antiguidade, como o uso do barrete frígio, a mania da utilização de nomes gregos e romanos, que é proibida pela Convenção e as juras «pela cabeça de Bruto» - no tempo do Terror feitas e recebidas com dignidade e respeito, são agora motivo de chacota $\left.{ }^{(111}\right)$.

Os poucos devotos do culto pela Grécia e Roma que restavam, uns desinteressam-se da actividade política; outros, como Billaud-Varenne e Babeuf, austeros e idealistas radicais, viram-se isolados e impotentes pela reacção conservadora do Termidor. Assim, no debate sobre a constituição de 1795 , os deputados invocaram a Antiguidade Clássica mais vezes para a condenarem do que para lhe manifestarem admiração (112).

(109) Vide J. de Romilly, Problèmes de la démocratie grecque, Paris, 1975 (em especial pp. 19-130).

(110) Vide M.I. Finley, «La constitución ancestral», in Uso y abuso de la historia (trad. esp.), Barcelona, 1977, pp. 45-90; A. Fuks, The Ancestral Constitucion. Four Studies in Athenian Party Politics at the End of the Fifth Century B.C., London, 1953, repr. Westport, 1975.

(111) Vide Parker, p. 179. Sobre o barrete frígio vide Aulard, Paris pendant la réaction thermidorienne et sous le Directoire, Paris, 1898-1902, I, p. 539.

(112) Vide Parker, p. 178; Diaz-Plaja, pp. 26-34. 
Como seria de esperar, a partir do 9 Termidor as críticas a Esparta aumentam e proporcionalmente observa-se um maior interesse pela sociedade ateniense. Embora com algumas ocorrências anteriores, como acontece num discurso de Chabot ${ }^{113}$, começa a manifestar-se então com mais insistência a ideia de que o ideal seria um compromisso entre o que se realizara em Esparta e o que Atenas fizera. E o que exprime Grégoire num relatório de 29 de Setembro de 1794, ao referir-se a Robespierre: reunir «le courage de Sparte et le génie d'Athènes» (114).

Tucídides, que fora praticamente desconhecido na «época das luzes» e nos primeiros tempos da Revolução, começa a aparecer no período do Termidor. Em 1795, no ano IV, surge a primeira tradução francesa moderna da sua obra, cujo autor, Pierre Charles Levesque, no "prefácio», exalta Tucídides como um historiador que tem muito a ensinar à França revolucionária ( $\left.{ }^{115}\right)$.

Começam também a aparecer, com alguma insistência, objecções ao culto dos Revolucionários pela Antiguidade Clássica: nota-se a incongruência entre esse culto, a defesa das liberdades e a escravatura que vigorava no mundo greco-romano.

Embora Grégoire já tivesse observado em 30 de Julho de 1793 que em Esparta existiam os hilotas $\left({ }^{116}\right)$, é sobretudo o historiador Volney que sublinha a incongruência do culto que os Revolucionários nutriam pelos gregos e pelos romanos ${ }^{117}$ ). Ironicamente escreve que, se os antepassados juravam por Jerusalém e pela Bíblia, os Revolucionários faziam-no por Esparta, Atenas e Tito Lívio, sem terem uma ideia clara da doutrina que pregam, sem repararem que os modelos que propõem são contrários ao que anunciam e às suas intenções: exaltam a liberdade da Grécia e de Roma e esquecem que em Esparta os servos, em muito maior número, são tratados como animais; que em Atenas, "ce sanctuaire de toutes libertés», havia a proporção de quatro escravos para um livre; que em toda a Grécia, para uma população de cerca de cinco milhões, mais de três

(113) Nesse discurso Chabot invoca Sólon e Licurgo e deseja que a República Francesa reuna as "virtudes das duas repúblicas rivais da Grécia». Le Moniteur, de 3 de Março de 1793 (apud Vidal-Naquet, p. 31 nota 79 ).

(114) Oeuvres de l'Abbé Grégoire...., cit., II, p. 277.

(115) Histoire de Thucydide fils d'Ölmes, trad. par P. Ch. Levesque, Paris, 1795 (4 vols.), Pref. pp. II, XI, XII, XXVII (apud Vidal-Naquet, pp. 34-35).

(116) Oeuvres complètes, II, p. 30.

(117) Oeuvres complètes, Paris, 1839, em esp. pp. $592-595$ (apud Vidal-Naquet, pp. 33-34). 
milhões eram escravos; que a desigualdade política e civil era um dogma aceite por povos e legisladores, consagrado por Licurgo e por Sólon, professado por Platão e Aristóteles, pelos generais e embaixadores de Esparta, Atenas e Roma (118).

Se os artistas, decoradores, escritores e dramaturgos continuavam a procurar na Antigudiade os temas para as suas obras; se as mulheres começam a vestir-se «à grega», a nível político o culto pela Grécia e Roma perdeu significado. Apenas manifestação isolada de um ou de outro. Nunca a vitalidade que motivara entre 1789 e 1794 acesas discussões e dera substância a verdadeiros confrontos ideológicos ${ }^{(119)}$.

De qualquer modo a Revolução Francesa, no que respeita à visão da Antiguidade Clássica, como em muitos outros domínios, passa a ser um marco nos tempos que se lhe seguem. Viveu em estreita sintonia com a cultura grega e romana, a ponto de identificar as figuras, factos e grupos da Hélade e de Roma com as figuras, factos e grupos da França revolucionária e vice-versa. E afinal o que, com toda a clareza, explicita Chateaubriand no livro, publicado em 1797, Essai historique sur les Révolutions: Licurgo é referido como "revolucionário» e como «legislador», as leis de Drácon comparadas aos decretos de Robespierre; o grupo regional ateniense dos «Diácrios», que, segundo Plutarco (Sólon 13.2), eram acérrimos partidários da democracia, é identificado, de acordo com o sentido do termo grego, com os «montanheses»; os jacobinos são assim assimilados aos espartanos e o «furor de conquista» da democracia ateniense aproximada das empresas francesas $\left({ }^{120}\right)$.

Não me parece, portanto, exacta a opinião dos que consideram o culto dos homens da Revolução Francesa pela Antiguidade Clássica como uma simples máscara ou um "adorno» sem importância real $\left({ }^{121}\right)$. Não se pode alegar que apenas a classe dirigente recebera uma educação clássica e fora tocada

(118) Oeuvres complètes, pp. 592-593. Colhi estas informações num texto citado em B. Hemmerdinger, "L'esclavagisme antique vu par le thermidorien Volney", Quaderni di Storia, 1 (1975), 115-116 e Vidal-Naquet, pp. 33-34; N. Rouland, Rome, démocratie impossible?, p. 282.

(119) Vide L. Bertrand, La fin du classicisme et le retour de l'antique, Genève, 1968, pp. 320-359; Diaz-Plaja, pp. 86-90, 94-97. Sobre o ncentuar da imitação clássica no vestuário depois do 9 Termidor, vide Diaz-Plaja, pp. 127-136.

(120) Essai sur les révolutions. Génie du Christianisme (Bibliothèque de la Pléiade), Paris, 1978, pp. 61-133 (em especial pp. 66, 70, 75-76, 79-118).

(121) Cf. G. Lefebvre na recensão a Parker, in Annales historiques de la Révolution française, 15 (1938), pp. 465-468 (apud Vidal-Naquet, p. 17 nota 26 ). 
pelo culto da Antiguidade greco-romana, se bem que esse seja um dado com algum apoio ${ }^{\left({ }^{122}\right)}$.

A cultura clássica foi sempre um marco de referência para os Revolucionários, em especial até 27 de Junho de 1794, e influenciou decisivamente a sua actuação, como o provam com evidência o labor legislativo de Saint-Just, os projectos educativos apresentados à Convenção e as propostas de reforma de Babeuf. Bem o sentiram os seus contemporâneos, como claramente se vê no texto de Volney e de Chateaubriand acima citados. São sintomas do mesmo sentimento, entre outros, a afirmação do Padre Grégoire num relatório de 29 de Setembro de 1794, no qual acusa Robespierre de, sob pretexto de os tornar espartanos, querer fazer deles hilotas e preparar um regime militar que não é senão o da tirania (123); o facto de Marx, além de manifestar o propósito de escrever um estudo sobre a razão pela qual Robespierre, Saint-Just e os seus partidários falharam, atribuir na Sagrada Família, publicada em 1845, esse fracasso a terem confundido o Estado realista e democrático antigo, que se baseava na escravatura real, com o Estado representativo espiritualista e democrático, baseado na escravatura emancipada - a sociedade burguesa (124).

Taine descreve o programa dos jacobinos como uma tentativa de voltar às instituições de Roma e de Esparta que eles tomaram como modelos $\left({ }^{125}\right)$.

Podemos portanto concluir que a camada dirigente da Revolução Francesa, sobretudo a mais radical, viveu em sintonia estreita com a cultura grega e romana, a ponto de identificar as figuras, factos e grupos da Hélade e de Roma com as figuras, factos e grupos da França revolucionária e vice-versa - possivelmente uma consequência da educação recebida nos estabelecimentos de ensino e do magistério dos autores das «luzes», em especial de Rousseau. Vendo em tais sociedades realizações ideais, essa camada dirigente adequa a própria actuação pela dos heróis e governantes da Antiguidade Clássica, tenta moldar a vida do seu país pelos modelos da Grécia e de Roma e procura dotar a França com várias das instituições aí existentes.

(122) E o que se pode deduzir do índice da obra de A. Soboul, Sans-culottes parisiennes de l'an II, Paris, 1958, no qual não figura Licurgo nem Sólon, mas aparece Bruto, como assassino de César ou de Tarquínio, um dos ídolos da Revolução, juntamente com Marat e Lepeletier (vide supra nota 7).

(123) Oeuvres de l'Abbé Grégoire cit., II, p. 267.

(124) Apud Vidal-Naquet, pp. 17-18.

(125) Les origines de la France contemporaine. La Révolution. III - Le gouvernement révolutionnaire, Paris, 1892, pp. 115 e 121. 